Article

\title{
Strategies to Manage the Impacts of the COVID-19 Pandemic in the Supply Chain: Implications for Improving Economic and Social Sustainability
}

\author{
Hasin Md. Muhtasim Taqi ${ }^{1}{ }^{10}$, Humaira Nafisa Ahmed ${ }^{1}$, Sumit Paul ${ }^{1}$, Maryam Garshasbi ${ }^{2}$, \\ Syed Mithun Ali ${ }^{1}{ }^{1}$, Golam Kabir ${ }^{2, *}$ a and Sanjoy Kumar Paul ${ }^{3}$ (1) \\ 1 Department of Industrial and Production Engineering, Bangladesh University of Engineering and Technology, \\ Dhaka 1205, Bangladesh; muhtasimtaqi.ipe@aust.edu (H.M.M.T.); humaira.mpe@aust.edu (H.N.A.); \\ sumitpaul398@gmail.com (S.P.); syed.mithun@gmail.com (S.M.A.) \\ 2 Industrial Systems Engineering, University of Regina, Regina, SK S4S 0A2, Canada; \\ maryam.garshasbi76@gmail.com \\ 3 UTS Business School, University of Technology Sydney, Sydney, NSW 2007, Australia; \\ sanjoy.paul@uts.edu.au \\ * Correspondence: golam.kabir@uregina.ca
}

Received: 10 October 2020; Accepted: 11 November 2020; Published: 14 November 2020

check for updates

\begin{abstract}
This paper aims to identify the negative impacts of the COVID-19 outbreak on supply chains and propose strategies to deal with the impacts in the context of the readymade garment (RMG) industry supply chain of an emerging economy: Bangladesh. To achieve the aims, a methodological framework is proposed through a literature review, expert inputs, and a decision-aid tool, namely the grey-based digraph-matrix method. A total of 10 types of negative impacts and 22 strategic measures to tackle the impacts were identified based on the literature review and expert inputs. Then, the grey-based digraph-matrix was applied for modeling the strategic measures based on their influence to deal with the impacts. Findings reveal that the strategies "manufacturing flexibility", "diversify the source of supply", and "develop backup suppliers" have significant positive consequences for managing the impacts of the COVID-19 pandemic in the RMG supply chain. The findings help industrial managers recover from supply chain disruptions by identifying and classifying the impacts and strategies required to manage the major supply chain disturbances caused by the COVID-19 pandemic. As a theoretical contribution, this study is one of few initial attempts to evaluate the impacts of the COVID-19 outbreak and the strategies to deal with the impacts in the supply chain context.
\end{abstract}

Keywords: COVID-19 outbreak; readymade garment industry; supply chain; impacts; strategies; grey digraph-matrix

\section{Introduction}

The COVID-19 is an infectious disease, which is creating a global catastrophe not only for human lives but also for economic activity, such as mining, supply chain, and logistics [1,2]. The World Health Organization (WHO) declared the COVID-19 outbreak as a global pandemic on 11 March 2020 [3]. The COVID-19 outbreak negatively impacted the automobile, readymade garments (RMG), travel, aircraft, manufacturing, telecommunications, food, and healthcare industries [4]. The COVID-19 outbreak's impacts on supply chains (SC) have already been brought to the attention of scholars [5] and business experts [6]. According to Fortune (2020), 94 percent of companies from the top 1000 companies in the world experienced SC interruptions because of the COVID-19 outbreak [7]. Moreover, global SCs 
experienced severe impacts, i.e., closed or somewhat closed factories, airports running with severe limitations, and medical equipment scarcities [8].

The components and character of SCs in the RMG sectors differ from company to company and depend on their goods, global strategy, target market, delivery delays, and supplier integration considerations [9]. Supply Chain Management (SCM) strategies are also different, as aspects of SCs vary in the RMG industry. If demand for products is unpredictable, strong emphasis should be placed on a consistent demand and supply volatility strategy. The RMG sector is full of uncertainty and volatility and the RMG industry is finding the instability, pace, range, sophistication, and complexities since the adoption of global SCs [10]. Multinational RMG companies are exposed to major risks frequently occurring, such as late deliveries, long lead times between returns and resending to clients, inventories and over-stocks, and single-solution deliveries [11]. However, dealing with an epidemic like COVID-19 is an unusual situation in this new globalized world [12]. The epidemic of COVID-19 first led to manufacturing delays of fashion goods in China, which then led to the closing of shops worldwide. The COVID 19 outbreak had severe economic consequences across the globe, product orders tend to be cancelled [13]. These order cancellations have made the business and SC very vulnerable.

As reported, due to the impact of COVID-19, demand for RMG goods has dropped dramatically. With the recent outbreak of COVID-19, the fragility of South Asian countries' clothing supply chain has been revealed. Millions of staff are out of jobs and look to an uncertain future [14]. The global $\mathrm{SC}$ has been disrupted, which makes a significant impact socially and economically. While demand is about to increase as lockdown controls become easier, the degree to which it will return is unclear. With more and more people working from home and going out less often, the essence of the demand for certain RMG products can be expected to alter. Most RMG companies are currently focusing on managing the impacts, with their strategies addressing the COVID-19 situation as a temporary problem. However, the value of sharing best practices for impact reduction is significant during the COVID-19 pandemic. Several mechanisms require that we center on understanding how to assess the plan, implement and sustain impact mitigation procedures, along with effective decision-making on who to provide decision-making on the chain of leadership.

Given the above discussion, the COVID-19 pandemic has shocked the global RMG industry. In such a rapidly changing situation, the RMG industry experiencing the outbreak of the COVID-19 pandemic have several commons follow up questions, i.e., for how long can SC withstand the impacts, how much time it needs for SC recover following the COVID-19 outbreak, what SC policy is the most effective for dealing with these effects at different epidemic dispersal levels of severity [8]. In order to answer these questions, this research was conducted. This research emphasises the following research questions:

1. What are the impacts on the supply chain due to the COVID-19 pandemic in the RMG sector?

2. What are the strategies to manage the impacts of the COVID-19 pandemic for the supply chains of the RMG industry?

3. Which strategies have more positive influences to deal with the impacts?

4. Can the effects of the strategies over the different impacts be quantified?

This study is conducted to address these questions. Therefore, the specific objectives of this study are:

(a) To identify the possible strategies to manage the impacts of the COVID-19 pandemic in the RMG supply chain context.

(b) To effectively rank the strategies using an integrated method of grey theory and digraph-matrix.

This paper contributes to the literature by proposing ways to identify the strategies to manage or recover from the impact of COVID-19 on RMG supply chains. In this study, ten crucial impacts and twenty-two strategies to manage the impacts have been established for the RMG supply chains. A combination of grey and digraph-matrix methodologies was used to identify and quantify strategies to deal with the impacts effectively. The remaining sections of this article is ordered as follows: 
Section 2 offers the literature review related to supply chain risks and strategies, existing approaches, proposed recovery strategies, and research gaps and contributions; Section 3 includes the framework to identify and quantify supply chain impact strategies for proposed methodologies using a combination of grey theory and digraph-matrix approaches.; Section 4 contains data collection, analysis, and implementation of the proposed methodology; Section 5 presents the results and discussion of findings. Section 6 describes the research implications for managers and policymakers. The conclusion and recommendation for further work are given in Section 7.

\section{Literature Review and Theoretical Development}

Each pandemic is unique, and due to this reason, it will be more challenging to forecast their impacts. Concerning SC activities, some scant details on past epidemic outbreaks can be retrieved. The pandemic situation significantly impacts every type of supply chain, i.e., the drug supply chain [15], and the food supply chain [16]. Fan, Jamison, and Summers [17] discussed the pandemic risk and estimated the possible annual income losses. Barua [18] illustrated the possible impacts of the COVID-19 pandemic using a standard macroeconomic model. The COVID-19 outbreak shows that pandemics can severely damage global supply chains. Hobbs [19] made an early assessment of the impact on food SC resistance and the potential disruption of food SC during the COVID-19 pandemic. Joshi et al. [20] studied the impact of the COVID-19 outbreak on exports of Indian fruits and vegetables and suggested future post-harvest SC policies. In China, with the exception of the basic sector, which was less affected, the majority of the industries were greatly affected by the COVID 19 outbreak [21]. The COVID-19 pandemic causes indirect value-added losses and direct losses [22] and also draws a substantial negative impact economically [23]. However, it has started to affect every type of supply chain network, i.e., negative impact on agricultural SC [24], scarcity of personal and protective equipment (PPE) [25], and ripple effects [26]. In this paper, ten impacts and twenty-two strategies are proposed based on the literature review, articles, and expert opinions (Table A1). In many previous studies, there are limitations. As an example, describing the impacts using standard macroeconomic models could be complicated and is incomplete [27]. The limitation of the threat assessment critical control point (TACCP) model is that it deals with threats assessment within a construction environment or within an organization. Still, its practical use to evaluate suppliers, that is, from the point of delivery, is problematic [28,29].

\subsection{RMG Supply Chain and the COVID-19 Pandemic}

Several types of research have been conducted to find the risk and impact strategies of the RMG supply chain. SCs must develop strategies for "digital readiness and data sharing" in pandemic situations like COVID-19 [30]. At the same time, "transport and production" and "job movement" could be the short-term focus in this case. The digital revolution of SCs could, under such circumstances, improve the reaction quality to epidemic disorders by increasing the operations and supply chain management (OSCM)-flexibility [31].

The RMG supply chain draws a substantial impact during pandemic situations. Son, Kang, and Jang [32] discussed the impact of order cancellation and out of stock in the RMG sector. Foremost brands delayed and canceled orders due to COVID-19, and millions of workers are at the risk of job losses [33]. Sánchez-Ramírez et al. [34] evaluated the impact of production process disruption in a glass factory. Unfilled orders [35], shipping delays [36], and stalled productions [37] are some common impacts on the global supply chain in the COVID-19 situation. Publicis Sapient's [38] report concluded that contingency plans should be created to change the delivery time. Tang and Zimmerman [39] discovered the importance of information and communication technology for managing excess inventory. Vidya and Prabheesh [40] published an article about the issues and activities of international trade in the COVID-19 pandemic. 


\subsection{Existing Multicriteria Decision-Making (MCDM) Approaches}

Sofyalığlu and Kartal [41] used the fuzzy analytic hierarchy process (FAHP) to select strategies for managing risks in the global iron and steel supply chain. Khan et al. [42] prioritized the risks in the management of a halal SC using the fuzzy best worst method (BWM). Ali et al. [43] proposed a grey-based decision making trial and evaluation laboratory (DEMATEL) model to find the interactions among the key food SCs risks. In addition, Surya et al. [44] analyzed risks for a perishable food SC and ranked the possible mitigation strategies using the interpretive structural modeling (ISM) technique. Shahbaz et al. [45] utilized the FAHP to assess risks in a halal food SC. Mzougui et al. [46] evaluated SC risks in the automotive industry through failure mode, effects, and criticality analysis (FMECA). Pourjavad and Shahin [47] proposed an integrated fuzzy DEMATEL and fuzzy technique for order of preference by similarity to ideal solution (TOPSIS) model for prioritizing the risks in a green supply chain (GSC). Moktadir et al. [48] evaluated risks in a sustainable supply applying the BWM technique. Chand et al. [49] proposed an analytical network process (ANP) model to select the best SC by risk analysis. Most of these studies focused on risk assessment rather than proposing strategies for managing disruption risks in supply chains. Few studies ranked risk mitigation strategies in the supply chain but did not model the influence of the strategies to deal with the impacts imposed by a disaster on the supply chain. To characterize such influences, this study employs the grey theory and digraph-matrix methods to manage supply chains in the context of the COVID-19 pandemic.

\subsection{Grey Theory and Digraph-Matrix Methods}

Grey theory and digraph-matrix methods are used to solve decision-making problems. Golinska et al. [50] suggested a grey decision-making tool to classify restructured operations to identify and prioritize companies' operations. Rajesh and Ravi [51] selected a resilient supplier in the supply chain using grey relation analysis. Chen et al. [52] used a grey incidence and clustering analysis to identify key indices for Chinese remanufacturing. In order to examine the effect of dynamic capabilities on the performance of a sustainable supply chain company, Mathivathanan, Govindan, and Haq [53] suggested the combination of grey relation analysis and analytical Hierarchy. Xue et al. [54] prioritized naval traffic security influencing factors using grey and fuzzy theories. Wang, Zhang, and Yang [55] prioritized failure modes by combining fuzzy sets theory and grey theory.

Liu et al. [56] represented the fuzzy digraph and matrix approach to determine the risk priorities of the failure modes of the systems, designs, products, processes, or services of an organization. Geetha and Sekar [57] presented the methodology and application of the graph theory matrix approach for evaluating the optimal combination of operating parameters of a diesel engine. Rajesh, Ravi, and Rao [58] proposed possible strategies and ranked them using a grey and digraph-matrix approach. Yue et al. [59] analyzed the dynamical system's global properties using a modified digraph cell mapping method. Srivastava et al. [60] presented a fuzzy digraph-matrix to analyze the risk of the compressed natural gas (CNG) dispensing unit. Dias et al. [61] developed a framework for evaluating the sustainability index using the graph theory matrix approach. In addition, Rajesh and Ravi [62] also proposed a blend of grey theory and DEMATEL approaches to rank the risk mitigation strategy in electronic SCs.

\subsection{Research Gaps and Contributions}

Identification and ranking of the strategies of COVID-19's negative impacts on the RMG have been the central focus of this study. In a situation like the COVID-19 pandemic, finding the impacts and strategies in the RMG industry is complicated. On the other hand, investigating SC strategies has commonly been studied under different situations and considered different industries. The strategies could play an essential role for the decision-makers to make strategic and premeditated decisions.

Over the years, the importance of identifying risk elements and potential strategies has grown, especially in the rice seed industry [44], the food and beverage industry [63], the toilet paper industry [64], 
the electric industry [65], etc. Organizations are giving importance to SC strategies identification because of several pandemic outbreaks, i.e., influenza outbreaks and cholera, which cause a substantial negative impact on their SC. Some research papers are related to the SC impact, i.e., recovering the impact of the COVID-19 on Alzheimer's virus [66], a production recovery plan in manufacturing SC [64], expecting the impacts of the pandemic on global SCs, etc. [67]. Several researchers work on short and long-term effects of a rapid response approach on the apparel industry [68], social sustainability issues in the clothing SC due to COVID-19 [67], and COVID-19 impact on the apparel industry [69]. Still, there is no research regarding strategies to manage or recover from the impact of COVID-19 on RMG supply chains. Most of the studies simply have ranked strategies, not focusing on the impact strategies. The existing studies did not rank the strategies to mitigate the impacts due to COVID-19. The paper uniquely contributes through ranking the strategies considering the impacts using a combination of grey theory and digraph-matrix approach. Similar studies on supply chain did not consider the COVID-19 case. These studies only considered arbitrary unforeseen emergency cases. For these reasons, the current study is a unique contribution to existing SC literature. In this research study, a combination of grey theory and digraph-matrix methods for efficiently recognizing and prioritizing strategies of the RMG industry assists in overcoming the research gap.

This research contributes to the literature as follows:

i. Identifying a comprehensive list of strategies to manage or recover from the impacts of COVID-19 outbreak on supply chains for the RMG industry from the literature review.

ii. Proposing a combination of grey theory and digraph-matrix methods for efficiently recognizing and prioritizing strategies to manage the impacts.

iii. Guiding decision-makers to make strategic and premeditated decisions to implement strategies in the context of the RMG successfully.

\section{Research Methodology}

The goal of this research work is to prioritize possible strategies leading to organizations providing a more efficient and robust supply chain system to manage significant impacts of the COVID-19 outbreak. Possible strategies are identified and further sorted out based on reliable feedback from experts' opinions and literature reviews. An integrated model of the grey based digraph-matrix approach has been proposed where the model has been used to establish a structured framework of the stated objective. This model is considered more reliable and rational in setting strategies as a priority since the suggested method prioritizes strategies with incomplete as well as vague information. However, the suggested model has been tested for the possible strategies for Bangladesh's readymade garments industry. A detailed flow chart of the proposed methodology has been discussed in the latter portion of this section.

\subsection{Grey System Theory}

Ju-Long [70] initially introduced and suggested grey system theory (GST) from a set of grey numbers, which can handle incomplete, limited, partial as well as uncertain judgments of the environment. It is also capable of handling imprecise information, which includes: unquantifiable knowledge, incomplete information, inaccurate information, and partial ignorance. In previous literature, it has been observed that GST performs better when a system has external boundaries structured or defined; on the contrary, its output deteriorates when the system's complexity as well as vagueness increases. Unlike GST, fuzzy mathematics reveals the opposite nature of results, restricted to internal uncertainty or vagueness but not to externally defined or formal boundaries. A system is called a grey system when the knowledge is partly understood by the degree of detail. In GST, notation $\otimes \mathrm{P}$ is a grey number that can be interpreted as an interval with a given lower limit value $(P)$ and upper limit value $(\bar{P})$. Thus, a grey system is presented as a system containing unknown details with a grey number and grey variables, as shown in the following Figure 1. 


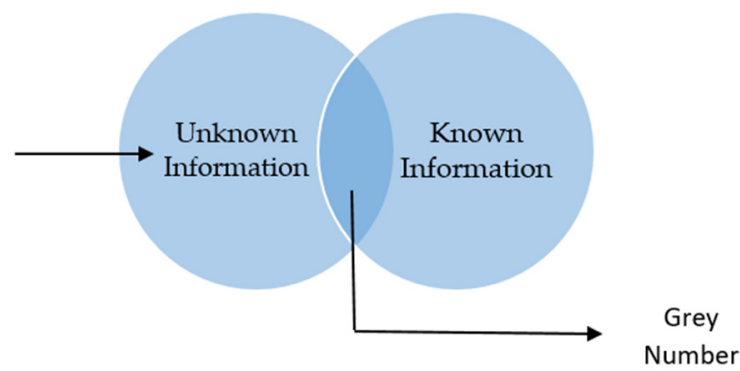

Figure 1. Grey system.

\subsection{Digraph-Matrix Theory}

The theory of 'digraph and matrix', which is based on "algebra graph theory" and "matrix" proved itself as a useful and efficient method in numerous cases since it has some attractive properties such as "modeling interactions of parameters", "capacity to produce hierarchical models", etc., to solve multiple problems [56,71]. A digraph consists of a collection of nodes and a collection of direct edges that represent the relative importance of the nodes. A node stands for the element, factor, or attribute represented by numbers [72]. A directional arrow or edge is drawn from factor to factor if there is relative importance or significance among cycle factors. Nonetheless, with the number of variables increasing and their interrelations, the digraph is complicated, and the digraph's visual analysis is expected to be intuitive. Hence, a matrix is used to represent the digraph while this constraint is being resolved.

\subsection{Proposed Model}

To assess the ranking of possible strategies, a blended grey theory and digraph-matrix were proposed. The research procedures are summarized as follows:

Step 1: Compute the initial relation matrices

Let $m$ be the number of identified impacts, and $n$ be the possible strategies for managing the identified $m$ impacts. Respondent $L$ has the task of ranking the importance of impact $i$ over impact $j$ and influence of strategy $x$ over impact $y$, where the respondents' total number is $K$. The rating on a scale of 0 to 4 reflects "no influence" to "very high influence" between $m$ impacts and $n$ possible strategies. Both positive and negative influences of strategy $x$ over impact $y$ will be evaluated on the same scale. Therefore, $3 \times K$ comparison matrices are established in this phase using the grey rating scale based on experts' judgments, opinions, and intuition. For example, if a respondent $L$ assigns a linguistic variable "very high influence-score 4 " to rank the importance of impact, it implies that respondent $L$ believes that impact $i$ has a very high influence over impact $j$. Similarly, if a respondent assigns a linguistic variable "no importance-score 0 " to rank the positive influence of strategy over impact, it implies that the respondent assumes strategy $x$ has no positive influence over impact $y$. In order to compare impacts over impacts, the positive influence of strategies over impacts, and the negative influence of strategies over impacts, the linguistic evaluation of $K$ respondents will, therefore, be defined.

Step 2: Changing the linguistic variable into the grey linguistic scale for average grey relation matrices.

The integer scale grading or ranking of importance amid impacts, the positive influence of possible strategies over impacts, and the negative influence of possible strategies over impacts will be transformed into corresponding grey scales defining an upper and lower range of values. The grey relation matrix $\otimes \mathrm{P}_{\mathrm{ij}}^{\mathrm{L}}$ is computed using Equation (1).

$$
\otimes \mathrm{P}_{\mathrm{ij}}^{\mathrm{L}}=\left(\underline{\otimes} \mathrm{P}_{\mathrm{ij}}^{\mathrm{L}}, \bar{\otimes} \mathrm{P}_{\mathrm{ij}}^{\mathrm{L}}\right)
$$

Similarly, the grey relation matrices are computed for $\otimes \mathrm{Q}_{x y}^{\mathrm{L}}, \otimes \mathrm{R}_{\mathrm{xy}}^{\mathrm{L}}$. Where $1 \leq L \leq K$; $1 \leq i \leq m ; 1 \leq j \leq m ; 1 \leq x \leq n ; 1 \leq y \leq m$. Thus, the initial relation matrices for $K$ respondents 
are transformed into grey relation matrices. The average grey relation matrix $\left[\otimes \widetilde{P}_{\mathrm{ij}}\right]$ can be determined from $k$ grey relation matrix using Equation (2). Using similar type of equations, the average grey relation matrices for $\left[\otimes \widetilde{Q}_{\mathrm{xy}}\right],\left[\otimes \widetilde{R}_{\mathrm{xy}}\right]$ are determined.

$$
\left[\otimes \widetilde{P}_{\mathrm{ij}}\right]=\frac{\sum_{L=1}^{K} \otimes \mathrm{P}_{\mathrm{ij}}^{\mathrm{L}}}{K}, \frac{\sum_{L=1}^{K} \bar{\otimes} \mathrm{P}_{\mathrm{ij}}^{\mathrm{L}}}{K}
$$

Step 3: Determine the crisp relation matrices from the average grey relation matrices.

Using the modified converting the fuzzy data into crisp scores method (CFCS), grey values can be transformed into crisp values. The CFCS method, introduced by Opricovic and Tzeng [73], is the process to defuzzify the global fuzzy weights into crisp scores. A modification has been made to the CFCS method in which de-graying has been used to arrive at a crisp number in a grey environment. There are three steps in the modified CFCS process in which the conversion from grey values to crisp values is accomplished $[74,75]$. The three steps are as follows:

(a) Normalization of the grey value

$$
\underline{\otimes P}_{\mathrm{ij}}=\left(\underline{\otimes}_{\mathrm{ij}}-\frac{\min }{j} \underline{\otimes}_{\mathrm{ij}}\right) / \Delta_{\min }^{\max }
$$

where $\otimes \dot{\mathrm{P}}_{\mathrm{ij}}$ represents the normalized lower limit value of the average grey number $\left[\otimes \widetilde{P}_{\mathrm{ij}}\right]$, similarly $\bar{\otimes} \dot{\mathrm{P}}_{\mathrm{ij}}$ represents the normalized upper limit value of the average grey number $\left[\otimes \widetilde{P}_{\mathrm{ij}}\right]$.

$$
\bar{\otimes} \dot{P}_{\mathrm{ij}}=\left(\bar{\otimes} \widetilde{P}_{\mathrm{ij}}-\frac{\min }{j} \bar{\otimes} \widetilde{P}_{\mathrm{ij}}\right) / \Delta_{\min }^{\max }
$$

Using similar type of equations normalized upper limit value $\bar{\otimes} \dot{Q}_{x y}, \bar{\otimes} R_{x y}$, and normalizaed lower limit value $\underline{\otimes} \dot{\mathrm{Q}}_{\mathrm{xy}}, \underline{\otimes} \mathrm{R}_{\mathrm{xy}}$ are determined where $\alpha_{\min }^{\max }$ and $\beta_{\min }^{\max }$ have been used. Here,

$$
\begin{aligned}
& \Delta_{\text {min }}^{\max }=\frac{m a x}{j} \bar{\otimes} \widetilde{P}_{\mathrm{ij}}-\frac{m i n}{j} \underline{\otimes} \widetilde{P}_{\mathrm{ij}} \\
& \alpha_{\text {min }}^{\max }=\frac{m a x}{y} \bar{\otimes} \widetilde{Q}_{\mathrm{xy}}-\frac{m i n}{y} \underline{\otimes}_{\mathrm{Q}} \\
& \beta_{\text {min }}^{\max }=\frac{\max }{y} \bar{\otimes} \widetilde{R}_{\mathrm{xy}}-\frac{m i n}{y} \widetilde{\otimes}_{\mathrm{xy}}
\end{aligned}
$$

(b) Computing total normalized crisp values

$$
\begin{aligned}
& \mathrm{a}_{\mathrm{ij}}=\frac{\left(\underline{\otimes} \dot{\mathrm{P}}_{\mathrm{ij}}(1-\underline{\otimes} \dot{\mathrm{P}} \dot{\mathrm{ij}})\right)+\left(\bar{\otimes} \dot{\mathrm{P}}_{\mathrm{ij}} \times \bar{\otimes} \dot{\mathrm{P}}_{\mathrm{ij}}\right)}{\left(1-\underline{\otimes} \dot{\mathrm{P}}_{\mathrm{ij}}+\bar{\otimes} \dot{\mathrm{P}}_{\mathrm{ij}}\right)} \\
& b_{x y}=\frac{\left(\underline{\otimes} \dot{Q}_{x y}\left(1-\underline{\otimes} \dot{Q_{x y}}\right)\right)+\left(\bar{\otimes} \dot{Q}_{x y} \times \bar{\otimes} \dot{Q}_{x y}\right)}{\left(1-\underline{\otimes} \dot{Q}_{x y}+\bar{\otimes} \dot{Q}_{x y}\right)} \\
& c_{x y}=\frac{\left(\underline{\otimes} R_{x y}^{\cdot}\left(1-\underline{\otimes} R_{x y}^{\prime}\right)\right)+\left(\bar{\otimes} R_{x y}^{\prime} \times \bar{\otimes} R_{x y}^{\prime}\right)}{\left(1-\underline{\otimes} R_{x y}^{\prime}+\bar{\otimes} R_{x y}^{\prime}\right)}
\end{aligned}
$$

(c) Calculating the final crisp value

$$
\mathrm{u}_{\mathrm{ij}}=\left(\min \underline{\otimes} \widetilde{P}_{\mathrm{ij}}+\left(\mathrm{a}_{\mathrm{ij}} \times \Delta_{\min }^{\max }\right)\right)
$$




$$
\begin{aligned}
& \mathrm{v}_{\mathrm{xy}}=\left(\min \underline{\otimes} \widetilde{Q}_{\mathrm{xy}}+\left(\mathrm{b}_{\mathrm{xy}} \times \alpha_{\min }^{\max }\right)\right) \\
& \mathrm{w}_{\mathrm{xy}}=\left(\min \underline{\otimes} \widetilde{R}_{\mathrm{xy}}+\left(\mathrm{c}_{\mathrm{xy}} \times \beta_{\min }^{\max }\right)\right)
\end{aligned}
$$

And,

$$
\begin{aligned}
\mathrm{U} * & =\left[\mathrm{u}_{\mathrm{ij}}\right] \\
\mathrm{V} * & =\left[\mathrm{v}_{\mathrm{xy}}\right] \\
\mathrm{W} * & =\left[\mathrm{w}_{\mathrm{xy}}\right]
\end{aligned}
$$

Step 4: Calculate the strategy selection matrices from the crisp relation matrices.

The selection of the possible strategies is achieved by generating strategy selection matrices for positive and negative influences of possible strategies over various forms of impacts. The positive strategy selection matrix consists of elements, $V_{i}$ on diagonals reflecting the positive influence of strategies over impacts $(1 \leq i \leq m)$ and $v_{i j}$ elements on rows are reflecting the importance of impacts $i$ over $j$. This matrix is defined as matrix $\mathrm{D}$; the permanent of the matrix gives the positive influence of possible strategies over impacts. Likewise, the matrix defined as $\mathrm{E}$ reflects both the negative influence of possible strategies over impacts and the significance of impacts. Consequently, the permanent of matrix E gives the negative influence of possible strategies over impacts. i.e.,

$$
\begin{aligned}
\mathrm{D} & =\left(\begin{array}{cccc}
\mathrm{v}_{1} & \mathrm{v}_{12} & \cdots & \mathrm{v}_{1 \mathrm{~m}} \\
\mathrm{v}_{21} & \mathrm{v}_{2} & \cdots & \mathrm{v}_{2 \mathrm{~m}} \\
\vdots & \vdots & \ddots & \vdots \\
\mathrm{v}_{\mathrm{m} 1} & \mathrm{v}_{\mathrm{m} 2} & \cdots & \mathrm{v}_{\mathrm{m}}
\end{array}\right) \\
\mathrm{E} & =\left(\begin{array}{cccc}
\mathrm{w}_{1} & \mathrm{w}_{12} & \cdots & \mathrm{w}_{1 \mathrm{~m}} \\
\mathrm{w}_{21} & \mathrm{~W}_{2} & \cdots & \mathrm{w}_{2 \mathrm{~m}} \\
\vdots & \vdots & \ddots & \vdots \\
\mathrm{w}_{\mathrm{m} 1} & \mathrm{w}_{\mathrm{m} 2} & \cdots & \mathrm{w}_{\mathrm{m}}
\end{array}\right)
\end{aligned}
$$

Step 5: Compute the permanent function of the matrices.

A matrix I, representing $\mathrm{N}$ parameters/criteria, has permanent function $\mathrm{N}$ ! (Factorial $\mathrm{N}$ ) terms grouped in $\mathrm{N}+1$ groups. However, these groups are the measurement of factors of parameter and loops of relative importance. Hence, matrices $\mathrm{D}$ and E's permanent function can be determined for $\mathrm{n}$ possible strategies.

Assume,

$$
I=\left(\begin{array}{cccc}
\mathrm{A}_{1} & \mathrm{a}_{12} & \cdots & \mathrm{a}_{1 \mathrm{~N}} \\
\mathrm{a}_{21} & \mathrm{~A}_{2} & \cdots & \mathrm{a}_{2 \mathrm{~N}} \\
\vdots & \vdots & \ddots & \vdots \\
\mathrm{a}_{\mathrm{N} 1} & \mathrm{a}_{\mathrm{N} 2} & \cdots & \mathrm{A}_{\mathrm{N}}
\end{array}\right)
$$

Step 6: Ranking of the strategies.

For $\mathrm{D}$ and $\mathrm{E}$ matrices, the permanent function values for $\mathrm{n}$ possible strategies have been determined. Per (D) reflects the positive impact of strategy $x$ over impacts, and per (E) typifies the negative impact of strategy over impacts. The calculation of the net positive influence values (NPIV) represents the net positive effect of strategy $x$ on the overall impacts i.e.,

$$
\mathrm{NPIV}=\operatorname{per}(\mathrm{D})-\operatorname{per}(\mathrm{E})
$$

The possible strategies are graded in the descending NPIV value order, based on their efficacy. The proposed methodology is summarized in Figure 2. 


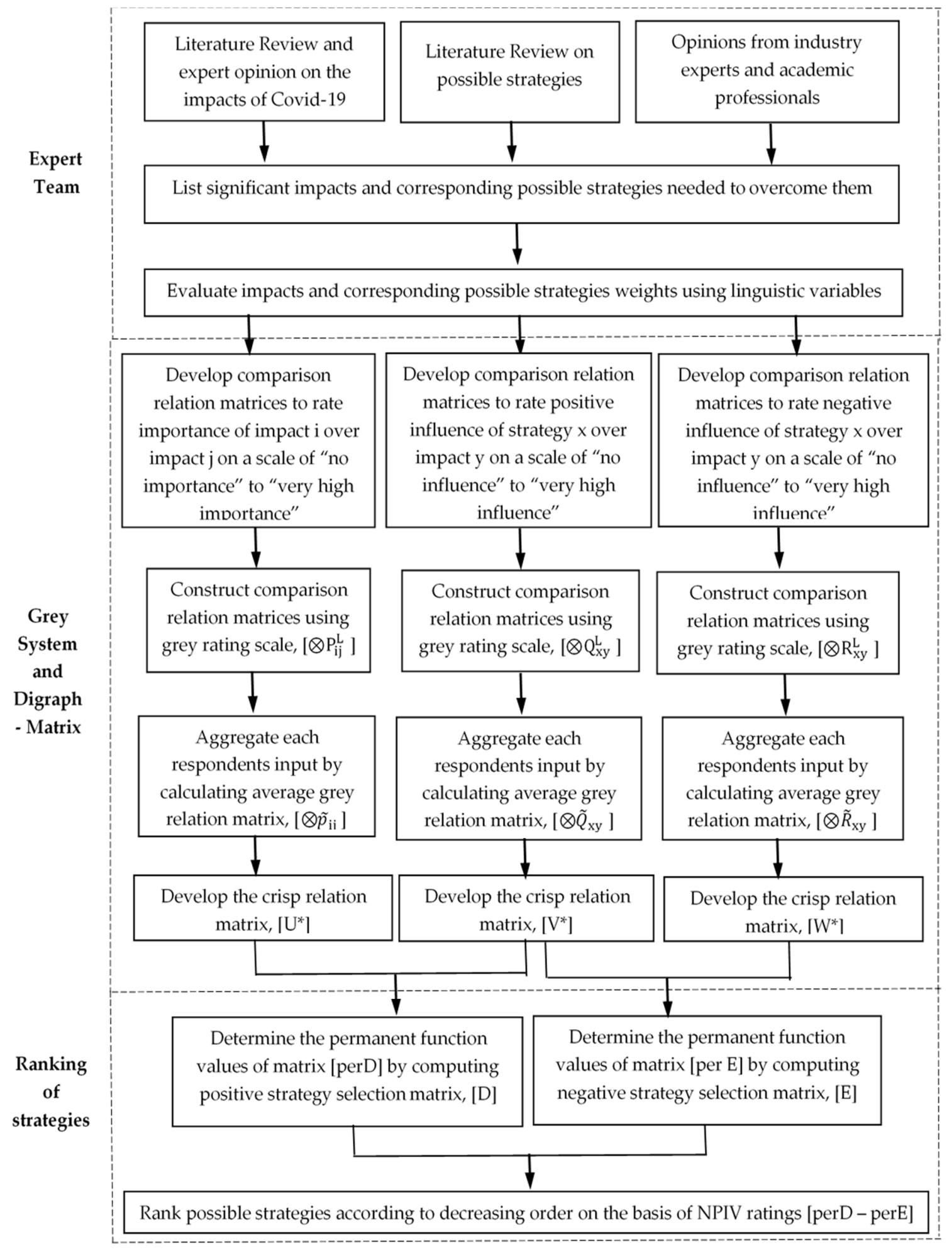

Figure 2. Proposed methodology.

\section{Data Collection and Analysis}

This section focuses on the implementation of the developed framework in the context of the RMG in an emerging economy like Bangladesh. 


\subsection{Company Profile}

ABC Fashion is a state of the art and uncompromising knit garments manufacturing set-up, with modern types of machinery. Besides knitting, the set-up also has fabric finishing, dyeing, embroidery, sewing, garment washing, print, finishing facilities, etc., fulfilling all the RMG industry's business needs. ABC Fashion started its journey in 1988 as a local textile manufacturer. Now, it is under Bangladesh's largest export-oriented (around US\$400 million) knit garments family, ABC group. Currently, ABC Fashion Ltd. exports around US\$80 million in a year, and around 8600 people are working for the RMG Company.

\subsection{Selection of Possible Impacts and Mitigation Strategies of COVID-19 Outbreak on the RMG Industry}

The preliminary list of impacts of COVID-19 and strategies to deal with the impacts determined from the literature survey was put in front of the experts. The expert team consisted of representatives from some top-ranked RMG companies in Bangladesh. The details and profile of the expert team member have been presented in Table A1 in the Appendix A. Several rounds of discussion sessions have been conducted with the expert team over the phone and face-to-face. The members were explained the essence of the study and its purposes. Based on the input from the expert team members and from the literature study, 10 possible impacts of the COVID-19 outbreak have been identified (Table 1 ).

Table 1. Possible impacts of COVID-19 outbreak on RMG supply chains.

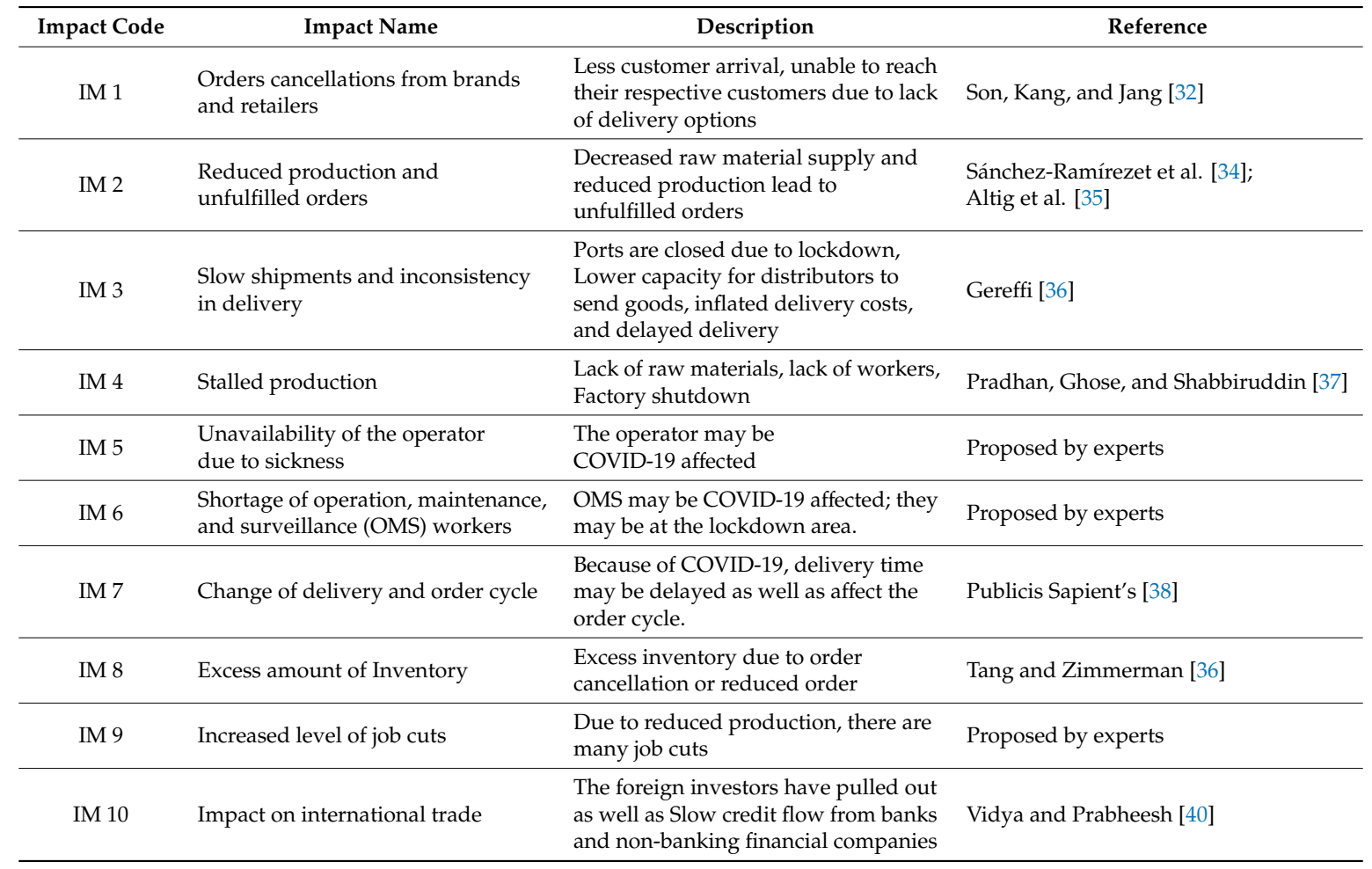

Based on the discussions and suggestions from the expert team, 22 possible managing strategies have been considered for further study. The responses are collected from each member individually through telephonic conversation or personal interviews, depending on their geographical location. The possible strategies to deal with the impacts of the COVID-19 outbreak in the RMG supply chain are presented in Table 2. 
Table 2. Possible strategies to deal with the impacts of COVID-19 outbreak in the RMG supply chain.

\begin{tabular}{|c|c|c|c|}
\hline Strategy Code & Strategies & Description & Reference \\
\hline MS 1 & Pricing flexibility & Price reduction by offering a discount. & Y. Wang and Yu [76] \\
\hline MS 2 & $\begin{array}{l}\text { Looking for alternative } \\
\text { buyers/markets }\end{array}$ & $\begin{array}{l}\text { Decreasing effect of canceled orders } \\
\text { due to COVID-19 outbreak }\end{array}$ & Proposed by experts \\
\hline MS 3 & $\begin{array}{l}\text { Diversify the source of supply and } \\
\text { develop backup suppliers }\end{array}$ & $\begin{array}{l}\text { Dividing up sourcing activities } \\
\text { between multiple suppliers serves to } \\
\text { protect a business against the impacts } \\
\text { on supply chain }\end{array}$ & Hou and Sun [77] \\
\hline MS 4 & Government incentives & $\begin{array}{l}\text { Government incentives are required } \\
\text { for the organizations when business } \\
\text { is stranded }\end{array}$ & Sharif [78] \\
\hline MS 5 & $\begin{array}{l}\text { AI and big data-based supply } \\
\text { chain transparency }\end{array}$ & $\begin{array}{l}\text { Integrate all the supply chain } \\
\text { information to avoid } \\
\text { possible disruptions }\end{array}$ & Proposed by experts \\
\hline MS 8 & $\begin{array}{l}\text { Using analytics to predict } \\
\text { net requirements }\end{array}$ & $\begin{array}{l}\text { Using advanced analytics and } \\
\text { experience to understand how } \\
\text { production or supply chain changes } \\
\text { affect inventory and operating capital. }\end{array}$ & Proposed by experts \\
\hline MS 9 & Keeping buffer inventory & $\begin{array}{l}\text { Decrease the effect of factory } \\
\text { shutdown keeping buffer inventory }\end{array}$ & Sen, Antara, Sen, and Chowdhury [80] \\
\hline MS 10 & $\begin{array}{l}\text { Introducing a generalized system } \\
\text { of preferences }\end{array}$ & Decreases capacity risks & Rajesh, Ravi, and Venkata Rao [58] \\
\hline MS 11 & $\begin{array}{l}\text { Health and safety training facilities } \\
\text { for the staff }\end{array}$ & $\begin{array}{l}\text { Train all the staff on COVID-19 } \\
\text { outbreak transmission systems, } \\
\text { methods, and implication }\end{array}$ & WHO [81] \\
\hline MS 14 & Flexible work shift or overtime & $\begin{array}{l}\text { Government restriction for in-house } \\
\text { gathering to prevent transmission of } \\
\text { COVID-19 outbreak }\end{array}$ & Kramer \& Kramer, [82] \\
\hline MS 15 & $\begin{array}{l}\text { A campaign of "social distancing" } \\
\text { measures such as isolation, work } \\
\text { from home, quarantine, etc. }\end{array}$ & Improved security system & Proposed by experts \\
\hline MS 16 & $\begin{array}{l}\text { Make backup operators } \\
\text { readily available }\end{array}$ & Basic OMS Training of staffs & Proposed by experts \\
\hline MS 17 & Supply chain design adjustment & $\begin{array}{l}\text { Adjusting strategies for } \\
\text { COVID-19 outbreak }\end{array}$ & $\begin{array}{l}\text { Novak and Loy, [83], } \\
\text { Rajesh, Ravi, and Venkata Rao [58] }\end{array}$ \\
\hline MS 18 & Increase agility & \multirow{3}{*}{$\begin{array}{l}\text { Prioritizing cost over responsiveness } \\
\text { for slow-moving product and vice } \\
\text { versa for fast-moving products, } \\
\text { making payment method flexible }\end{array}$} & \multirow{3}{*}{$\begin{array}{l}\text { Parast, [84], } \\
\text { Rajesh, Ravi, and Venkata Rao [58] }\end{array}$} \\
\hline MS 19 & Flexible payment method & & \\
\hline MS 20 & $\begin{array}{l}\text { Attracting more buyers offering } \\
\text { products at lower price }\end{array}$ & & \\
\hline MS 21 & $\begin{array}{l}\text { Increase the number of } \\
\text { contractual workers }\end{array}$ & $\begin{array}{l}\text { Decreases liability and reduces the } \\
\text { probability of firing } \\
\text { permanent workers }\end{array}$ & Proposed by experts \\
\hline MS 22 & $\begin{array}{l}\text { Globally coordinated policy for } \\
\text { effective control }\end{array}$ & $\begin{array}{l}\text { - Sharing information with supply } \\
\text { chain partners located globally } \\
\text { - Provide funding by government/ } \\
\text { banks with less or no interest } \\
\text { - Multi-layered international and } \\
\text { Intra- and inter-organizational } \\
\text { coordination }\end{array}$ & $\begin{array}{l}\text { Baofeng Huo, Muhammad Zia Ul Haq } \\
\text { \& Minhao Gu, [85] }\end{array}$ \\
\hline
\end{tabular}

This study has merged the grey theory with digraph- matrix methods to define the best and most effective strategy to manage the impacts of the COVID-19 pandemic on the RMG supply chain and to distinguish the possible strategies based on their effectiveness in managing the impacts. The method ranks the mitigation strategies considering the importance of the relationship of the SC risks and the 
positive and negative influence of the mitigation strategies on the impacts. The importance relation among impacts of COVID-19 on SC and positive and negative influences of mitigation strategies on the impacts are represented as digraphs, as shown in Figures 3 and 4.

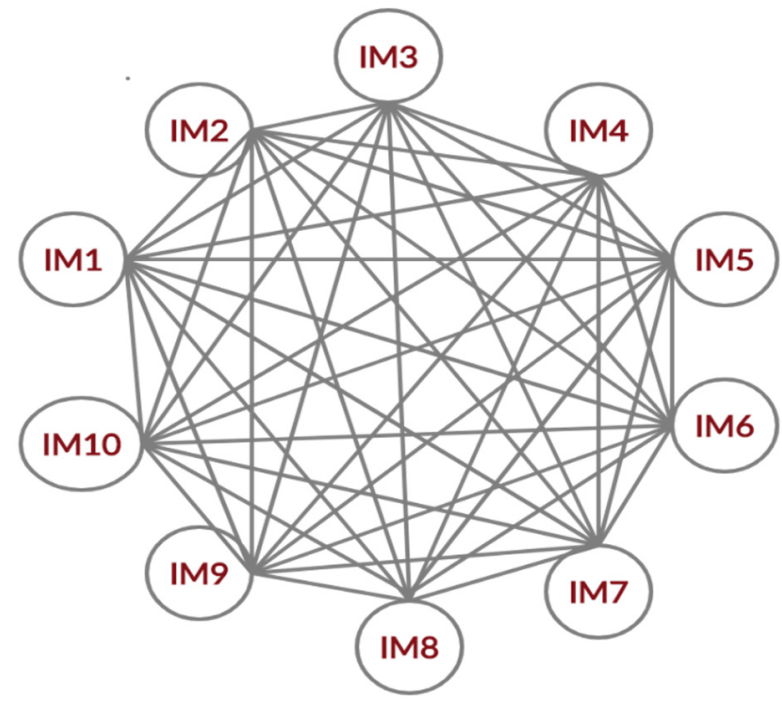

Figure 3. Digraph to represent the importance relationships among the impacts.

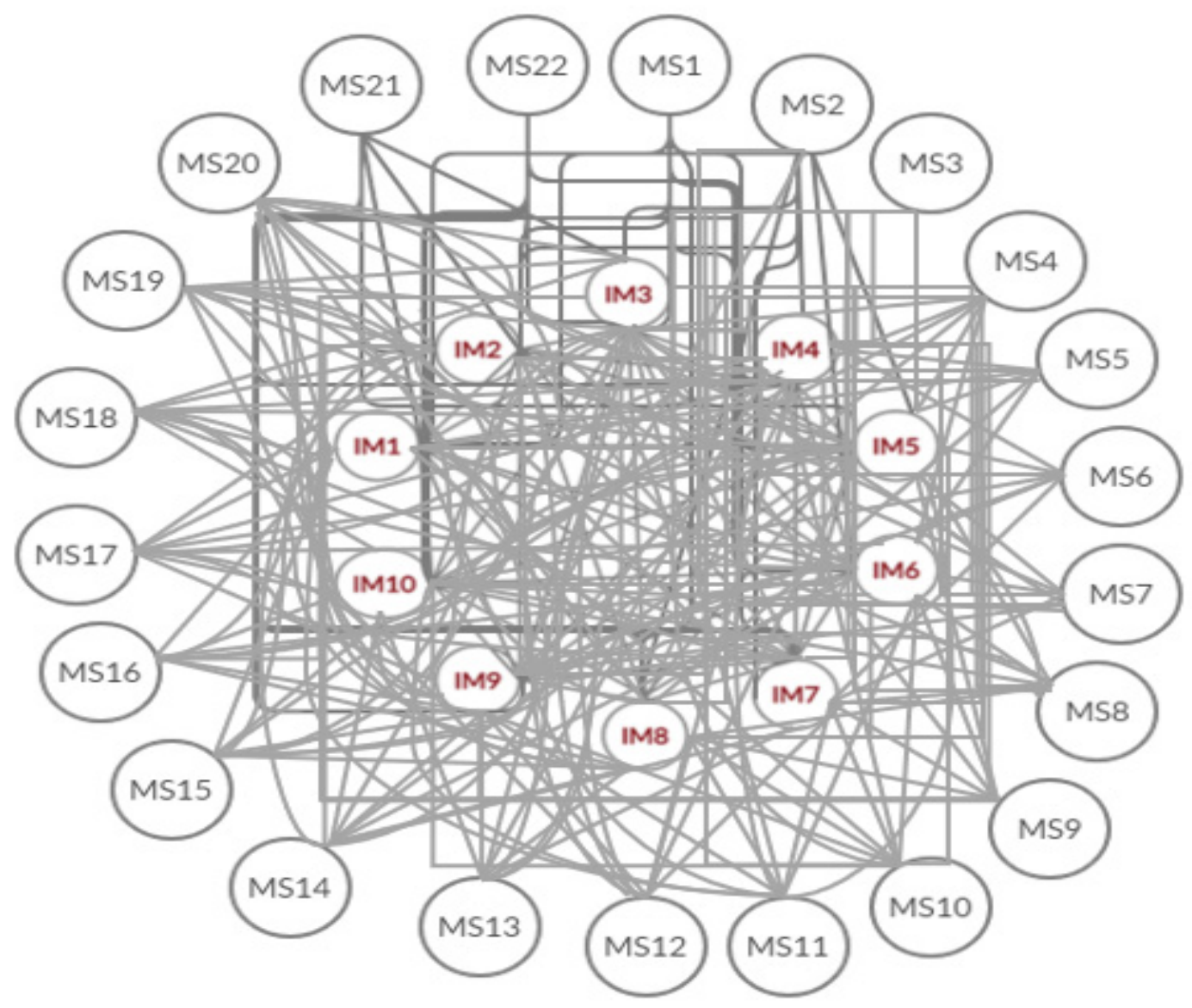

Figure 4. Digraph to represent the the influences of mitigation strategies on impacts. 


\subsection{Data Collection and Implication of Grey-Digraph-Matrix Method}

In this section, the ranking of possible strategies to alleviate the impacts of COVID-19 outbreak on the supply chain of readymade garments has been explained by grey-digraph-matrix approach. The task of rating the influence of possible strategies on impacts was granted to a group of three supply chain experts from the tested firm ABC. Expert descriptions are mentioned in Table 3.

Table 3. Experts and their designation for analyzing strategies.

\begin{tabular}{ccc}
\hline Expert Code & Designation & Experience \\
\hline Exp 1 & Head of Operations & 25 years \\
\hline Exp 2 & Head of Sales and Marketing & 20 years \\
\hline Exp 3 & Head of Supply Chains & 18 years \\
\hline
\end{tabular}

The list of impacts of the COVID-19 pandemic and strategies were e-mailed to the experts presented in Table 3. The experts have assessed the importance of one impact over other impacts. Besides, they have rated the influence of possible strategies over the impacts of the COVID-19 outbreak. The grey numbers presented in Table 4 represent the five-point scale that has been used for pairwise comparison of rating and evaluation.

Table 4. Grey Linguistic Rating [86].

\begin{tabular}{ccc}
\hline Linguistic Variable & Score & Grey Number \\
\hline No Importance/Influence & 0 & {$[0,0]$} \\
\hline Very Low Importance/Influence & 1 & {$[0,0.25]$} \\
\hline Low Importance/Influence & 2 & {$[0.25,0.5]$} \\
\hline High Importance/Influence & 3 & {$[0.5,0.75]$} \\
\hline Very High Importance/Influence & 4 & {$[0.75,1]$} \\
\hline
\end{tabular}

Initial relation matrices to rate the importance of one impact over other impacts, positive influence of possible strategies over impacts, and negative influence of possible strategies over impacts have been developed using expert input displayed in Tables S1-S5. After collecting the pairwise comparison matrices (Tables S1-S5), the matrices were converted into grey relation matrices that eventually resulted in three $10 \times 10$ grey relation matrices representing the importance of impacts, and six $22 \times 10$ initial grey relation matrices representing the influence of possible strategies over impacts shown in Tables S6-S11. With aggregation, the average grey value $\left[\otimes \widetilde{P}_{\mathrm{ij}}^{\mathrm{L}}\right]$ has been determined from the initial matrices displayed in Tables S12 and S13. Following this, the crisp relation matrix [ $\left.\mathrm{U}^{*}\right]$ among impacts has been determined in Table 5. Similarly, the crisp relation matrices for the positive influence of possible strategies over impacts, the negative influence of possible strategies over impacts $\left[\mathrm{V}^{*}\right]$ and $\left[\mathrm{W}^{*}\right]$ have been determined, respectively, in Tables 6 and 7. In the next step, the possible strategy selection matrices $\mathrm{D}$ and $\mathrm{E}$ have been developed for the positive influence of possible strategies over impacts and negative influence of possible strategies over impacts, respectively. The permanent function of the positive influence of possible strategies over impacts and negative influence of possible strategies over impacts were calculated in Tables 8 and 9.

Similarly, crisp relation matrices have been developed for the positive influence of possible strategies over the impacts and the negative influence of possible strategies. 
Table 5. Crisp relation matrix displaying relative importance of impacts using step three mentioned on methodology.

\begin{tabular}{ccccccccccc}
\hline \multicolumn{1}{c}{} & \multicolumn{1}{c}{ Final Crisp Value } \\
\hline IM 1 & IM 2 & IM 3 & IM 4 & IM 5 & IM 6 & IM 7 & IM 8 & IM 9 & IM 10 \\
\hline IM 1 & 0 & 0 & 0 & 0 & 0.35 & 0 & 0.56 & 0.28 & 0.59 & 0.44 \\
\hline IM2 & 0 & 0 & 0.07 & 0 & 0 & 0.21 & 0 & 0 & 0 & 0 \\
\hline IM 3 & 0 & 0.42 & 0 & 0 & 0 & 0 & 0 & 0 & 0 & 0 \\
\hline IM 4 & 0 & 0 & 0 & 0 & 1.55 & 1.55 & 0.63 & 2.38 & -32.61 & 0 \\
\hline IM 5 & 0 & 0 & 9.95 & 0 & 0 & 0 & 0.63 & 0.63 & 0 & 0.74 \\
\hline IM 6 & 0 & 0 & 0 & 0 & 0 & 0 & 1.11 & 0.63 & 0 & 0 \\
\hline IM 7 & 0 & 0 & 0 & 0 & 0.30 & 0.21 & 0 & 0 & 0 & 0 \\
\hline IM 8 & 0 & 0 & 0.42 & 0.21 & 0.75 & 0 & 0.21 & 0 & 0.42 & 0 \\
\hline IM 9 & 0.75 & 0.75 & 0.56 & 0.49 & 0.49 & 0.49 & 0.42 & 0.63 & 0 & 0.21 \\
\hline IM 10 & 0.21 & 0.63 & 0 & 0.58 & 0.42 & 0.42 & 0.42 & 0.56 & 0.63 & 0 \\
\hline
\end{tabular}

Table 6. Crisp relation matrix displaying the relative positive influence of possible strategies over impacts.

\begin{tabular}{|c|c|c|c|c|c|c|c|c|c|c|}
\hline \multicolumn{11}{|c|}{ Final Crisp Value } \\
\hline & IM 1 & IM 2 & IM 3 & IM 4 & IM 5 & IM 6 & IM 7 & IM 8 & IM 9 & IM 10 \\
\hline MS 1 & 0 & 0.0395 & 0 & 0 & 0.5221 & 0.0049 & 0.8117 & 0.4256 & 0.7594 & 0.5742 \\
\hline MS 2 & 0 & 0.2037 & 0.093 & 0.0185 & 0.0185 & 0.3291 & 0 & 0 & 0 & 0 \\
\hline MS 3 & 0.1366 & 0.6186 & 0 & 0 & 0 & 0 & 0 & 0 & 0 & 0 \\
\hline MS 4 & 0 & 0 & 0 & 0 & 0.8879 & 0.8879 & 0.9082 & 0.7473 & 14.426 & 0 \\
\hline MS 5 & 0 & 0 & -1.4605 & 0 & 0 & 0 & 0.9082 & 0.9082 & 0 & 0.9446 \\
\hline MS 6 & 0 & 0 & 0 & 0 & 0 & 0 & 0.6661 & 0.9082 & 0 & 0.0395 \\
\hline MS 7 & 0 & 0 & 0.0395 & 0 & 1.0136 & 0.3291 & 0 & 0 & 0 & 0 \\
\hline MS 8 & 0 & 0.2704 & 0.6186 & 0.3291 & 0.75 & 0 & 0.3291 & 0 & 0.6186 & 0 \\
\hline MS 9 & 0.75 & 0.75 & 0.8117 & 0.7151 & 0.7151 & 0.7151 & 0.6186 & 0.9082 & 0 & 0.3291 \\
\hline MS 10 & 0.3291 & 0.9082 & 0.1366 & 0.5833 & 0.6186 & 0.6186 & 0.6186 & 0.8117 & 0.9082 & 0 \\
\hline MS 11 & 0 & 0.0395 & 0 & 0 & 0.5221 & 0.0049 & 0.8117 & 0.4256 & 0.7594 & 0.5742 \\
\hline MS 12 & 0 & 0.2037 & 0.09316 & 0.0185 & 0.0185 & 0.3291 & 0 & 0 & 0 & 0 \\
\hline MS 13 & 0.1366 & 0.6186 & 0 & 0 & 0 & 0 & 0 & 0 & 0 & 0 \\
\hline MS 14 & 0 & 0 & 0 & 0 & 0.8879 & 0.887 & 0.9082 & 0.7473 & 14.426 & 0 \\
\hline MS 15 & 0 & 0 & -1.460 & 0 & 0 & 0 & 0.9082 & 0.9082 & 0 & 0.9446 \\
\hline MS 16 & 0 & 0 & 0 & 0 & 0 & 0 & 0.6661 & 0.9082 & 0 & 0.0395 \\
\hline MS 17 & 0 & 0 & 0.0395 & 0 & 1.0136 & 0.3291 & 0 & 0 & 0 & 0 \\
\hline MS 18 & 0 & 0.2704 & 0.6186 & 0.3291 & 0.75 & 0 & 0.3291 & 0 & 0.6186 & 0 \\
\hline MS 19 & 0.75 & 0.75 & 0.8117 & 0.7151 & 0.7151 & 0.7151 & 0.6186 & 0.9082 & 0 & 0.3291 \\
\hline MS 20 & 0.3291 & 0.9082 & 0.1366 & 0.5833 & 0.6186 & 0.6186 & 0.6186 & 0.8117 & 0.9082 & 0 \\
\hline MS 21 & 0 & 0.0395 & 0 & 0 & 0.5221 & 0.0049 & 0.8117 & 0.4256 & 0.7594 & 0.5742 \\
\hline MS 22 & 0 & 0.0395 & 0 & 0 & 0.5221 & 0.0049 & 0.8117 & 0.4256 & 0.7594 & 0.5742 \\
\hline
\end{tabular}


Table 7. Crisp relation matrix displaying the relative negative influence of possible strategies over impacts.

\begin{tabular}{|c|c|c|c|c|c|c|c|c|c|c|}
\hline \multicolumn{11}{|c|}{ Final Crisp Value } \\
\hline & IM 1 & IM 2 & IM 3 & IM 4 & IM 5 & IM 6 & IM 7 & IM 8 & IM 9 & IM 10 \\
\hline MS 1 & 0 & 0.0238 & 0.0238 & 0.0064 & 0.1225 & 0 & 0.0833 & 0.0064 & 0.1225 & 0.0238 \\
\hline MS 2 & 0.05 & 0.0833 & 0.05 & 0.0238 & 0.1225 & 0.1666 & 0.1225 & 0.6944 & 0.5 & 0.0064 \\
\hline MS 3 & 0.0064 & 0.1225 & 0.05 & 0.05 & 0.05 & 0.05 & 0.1666 & 0.1666 & 0.05 & 0.0064 \\
\hline MS 4 & 0 & 0 & 0.0238 & 0.0064 & 0.4384 & 0.2666 & 0.1225 & 0.1225 & 0.6282 & 0 \\
\hline MS 5 & 0.05 & 0.05 & 0.9704 & 0.0238 & 0.0833 & 0.05 & 0.1225 & 0.1666 & 0 & 0.3214 \\
\hline MS 6 & 0.0064 & 0.05 & 0.0238 & 0.0833 & 0.1666 & 0.05 & 0.5 & 0.1666 & 0.1225 & 0 \\
\hline MS 7 & 0.05 & 0.05 & 0.1225 & 0.05 & 0.2149 & 0.05 & 0.05 & 0.05 & 0.0238 & 0.0064 \\
\hline MS 8 & 0.0833 & 0.1666 & 0.1225 & 0.1666 & 0.2149 & 0.0833 & 0.1225 & 0.1225 & 0.1225 & 0.0064 \\
\hline MS 9 & 0.0833 & 0.2666 & 0.02381 & 0.1666 & 0.1666 & 0.1666 & 0.1225 & 0.1666 & 0.05 & 0.0064 \\
\hline MS 10 & 0.0064 & 0.05 & 0.02381 & 0.0238 & 0.2149 & 0.0833 & 0.1225 & 0.6944 & 0.8304 & 0 \\
\hline MS 11 & 0.05 & 0.05 & 0.1666 & 0.0238 & 0.0833 & 0.0238 & 0.2666 & 0.2149 & 0.05 & 0.0833 \\
\hline MS 12 & 0.0064 & 0.0833 & 0 & 0.05 & 0.05 & 0.08333 & 0.0833 & 0.1666 & 0.05 & 0 \\
\hline MS 13 & 0 & 0.0238 & 0.0238 & 0.0064 & 0.1225 & 0.0064 & 0.0064 & 0 & 0.0238 & 0 \\
\hline MS 14 & 0.05 & 0.05 & 0.1225 & 0.05 & 0.5633 & 0.3787 & 0.1666 & 0.1225 & 0.6282 & 0.0064 \\
\hline MS 15 & 0.0833 & 0.1666 & 0.9704 & 0.1225 & 0.1225 & 0.1225 & 0.2666 & 0.3214 & 0.05 & 0.3214 \\
\hline MS 16 & 0.0064 & 0.05 & 0.0238 & 0.0833 & 0.1225 & 0.0238 & 0.4384 & 0.1225 & 0.1225 & 0 \\
\hline MS 17 & 0.05 & 0.1225 & 0.05 & 0.0238 & 0.0833 & 0.05 & 0.0238 & 0.05 & 0 & 0.0064 \\
\hline MS 18 & 0.0064 & 0.05 & 0.0238 & 0.0833 & 0.3214 & 0.1666 & 0.2149 & 0.6944 & 0.8304 & 0 \\
\hline MS 19 & 0.05 & 0.05 & 0.2149 & 0.0833 & 0.1666 & 0.05 & 0.1666 & 0.1666 & 0.0238 & 0.0238 \\
\hline MS 20 & 0.0833 & 0.1666 & 0.05 & 0.05 & 0.05 & 0.05 & 0.0833 & 0.3214 & 0.05 & 0.0064 \\
\hline MS 21 & 0.0064 & 0.05 & 0 & 0.05 & 0.2149 & 0.0833 & 0.1666 & 0.0833 & 0.1666 & 0.0238 \\
\hline MS 22 & 0 & 0.0064 & 0.0833 & 0.0238 & 0.1666 & 0.0064 & 0.0238 & 0 & 0.0833 & 0 \\
\hline
\end{tabular}

Table 8. Permanent function matrix displaying the positive influence of strategies over impacts (D).

\begin{tabular}{cccccccccc}
\hline $\mathbf{V}_{\mathbf{1}}$ & 0 & 0 & 0 & 0.3510 & 0 & 0.5619 & 0.2808 & 0.5931 & 0.4447 \\
\hline 0 & $\mathbf{V}_{\mathbf{2}}$ & 0.0784 & 0 & 0 & 0.2105 & 0 & 0 & 0 & 0 \\
\hline 0 & 0.4213 & $\mathbf{V}_{\mathbf{3}}$ & 0 & 0 & 0 & 0 & 0 & 0 & 0 \\
\hline 0 & 0 & 0 & $\mathbf{V}_{\mathbf{4}}$ & 1.5597 & 1.5597 & 0.632 & 2.3803 & -32.6148 & 0 \\
\hline 0 & 0 & 9.9532 & 0 & $\mathbf{V}_{\mathbf{5}}$ & 0 & 0.6322 & 0.63232 & 0 & 0.7416 \\
\hline 0 & 0 & 0 & 0 & 0 & $\mathbf{V}_{\mathbf{6}}$ & 1.1132 & 0.6322 & 0 & 0 \\
\hline 0 & 0 & 0 & 0 & 0.3078 & 0.2105 & $\mathbf{V}_{\mathbf{7}}$ & 0 & 0 & 0 \\
\hline 0 & 0 & 0.4213 & 0.2105 & 0.7509 & 0 & 0.2105 & $\mathbf{V}_{\mathbf{8}}$ & 0.42133 & 0 \\
\hline 0.7509 & 0.7509 & 0.5619 & 0.4916 & 0.4916 & 0.4916 & 0.4213 & 0.6322 & $\mathbf{V}_{\mathbf{9}}$ & 0.2105 \\
\hline 0.2105 & 0.632 & 0 & 0.5839 & 0.4213 & 0.4213 & 0.4213 & 0.56191 & 0.6322 & $\mathbf{V}_{\mathbf{1 0}}$ \\
\hline
\end{tabular}


Table 9. Permanent function matrix displaying the negative influence of strategies over impacts (E).

\begin{tabular}{cccccccccc}
\hline $\mathbf{W}_{\mathbf{1}}$ & 0 & 0 & 0 & 0.3510 & 0 & 0.5619 & 0.2808 & 0.5931 & 0.4447 \\
\hline 0 & $\mathbf{W}_{\mathbf{2}}$ & 0.0784 & 0 & 0 & 0.2105 & 0 & 0 & 0 & 0 \\
\hline 0 & 0.4213 & $\mathbf{W}_{\mathbf{3}}$ & 0 & 0 & 0 & 0 & 0 & 0 & 0 \\
\hline 0 & 0 & 0 & $\mathbf{W}_{\mathbf{4}}$ & 1.5597 & 1.5597 & 0.6322 & 2.3803 & -32.6148 & 0 \\
\hline 0 & 0 & 9.9532 & 0 & $\mathbf{W}_{\mathbf{5}}$ & 0 & 0.6322 & 0.6322 & 0 & 0.7416 \\
\hline 0 & 0 & 0 & 0 & 0 & $\mathbf{W}_{\mathbf{6}}$ & 1.1132 & 0.6322 & 0 & 0 \\
\hline 0 & 0 & 0 & 0 & 0.3078 & 0.2105 & $\mathbf{W}_{\mathbf{7}}$ & 0 & 0 & 0 \\
\hline 0 & 0 & 0.4213 & 0.2105 & 0.7509 & 0 & 0.2105 & $\mathbf{W}_{\mathbf{8}}$ & 0.4213 & 0 \\
\hline 0.7509 & 0.7509 & 0.5619 & 0.4916 & 0.4916 & 0.4916 & 0.4213 & 0.6322 & $\mathbf{W}_{\mathbf{9}}$ & 0.2105 \\
\hline 0.2105 & 0.6322 & 0 & 0.5839 & 0.4213 & 0.4213 & 0.4213 & 0.5619 & 0.6322 & $\mathbf{W}_{\mathbf{1 0}}$ \\
\hline
\end{tabular}

\section{Results and Discussions}

\subsection{Discussion on the Findings}

According to Equation (20), NPIV values were calculated for the strategies. The possible strategies were ranked in the ascending order of the NPIV values. The ranking of the NPIV values is presented in Table 10.

Table 10. Ranking of strategies.

\begin{tabular}{|c|c|c|c|c|}
\hline Strategy & Per (D) & Per (E) & NPIV & Rank \\
\hline MS 7 & -1.2802 & -3.8688 & 2.5886 & 1 \\
\hline MS 3 & -0.9208 & -2.4776 & 1.5568 & 2 \\
\hline MS 12 & -1.469 & -2.0219 & 0.5529 & 3 \\
\hline MS 17 & -1.2802 & -1.623 & 0.3428 & 4 \\
\hline MS 18 & -4.1754 & -3.9085 & -0.2669 & 5 \\
\hline MS 13 & -1.6747 & -1.281 & -0.3937 & 6 \\
\hline MS 4 & -2.6059 & -2.0845 & -0.5214 & 7 \\
\hline MS 2 & -4.6474 & -3.5555 & -1.0919 & 8 \\
\hline MS 8 & -4.1754 & -2.4619 & -1.7135 & 9 \\
\hline MS 6 & -6.178 & -3.8988 & -2.2792 & 10 \\
\hline MS 16 & -6.178 & -3.3972 & -2.7808 & 11 \\
\hline MS 15 & -8.2864 & -5.3848 & -2.9016 & 12 \\
\hline MS 19 & -5.8082 & -2.6276 & -3.1806 & 13 \\
\hline MS 11 & -6.843 & -3.2602 & -3.5828 & 14 \\
\hline MS 14 & -7.3064 & -2.5106 & -4.7958 & 15 \\
\hline MS 1 & -6.6461 & -1.6591 & -4.987 & 16 \\
\hline MS 5 & -8.2864 & -3.2741 & -5.0123 & 17 \\
\hline MS 22 & -6.843 & -1.4129 & -5.4301 & 18 \\
\hline MS 10 & -13.6541 & -3.3514 & -10.3027 & 19 \\
\hline MS 21 & -13.6541 & -2.2169 & -11.4372 & 20 \\
\hline MS 9 & -49.1749 & -2.5281 & -46.6468 & 21 \\
\hline MS 20 & -55.1254 & -2.6315 & -52.4939 & 22 \\
\hline
\end{tabular}


The NPIV values are plotted in Figure 5. From Figure 5, the most prominent four strategies, which have the highest positive NPIV values, are MS $7>$ MS $3>$ MS $12>$ MS 17 (Manufacturing flexibility, Diversify the source of supply and develop backup suppliers, Train backup operators, Supply chain design adjustment). From Table 10, it can be observed that "Manufacturing Flexibility" has the highest NPIV resulted in the most significant managing strategy. Manufacturing flexibility ensures more product variation and decreases risks. "Diversify the source of supply" and "Develop backup suppliers" stand as the $2^{\text {nd }}$ and $3^{\text {rd }}$ most relevant possible strategies. Diversified source of supply and backup suppliers decreases supply chain risks by continuing sourcing of raw materials during pandemics. However, it is also observed that the strategy of "Attracting more buyers offering products at a lower price" has got the lowest NPIV value, indicating the least significant strategies to manage the impacts of COVID-19.

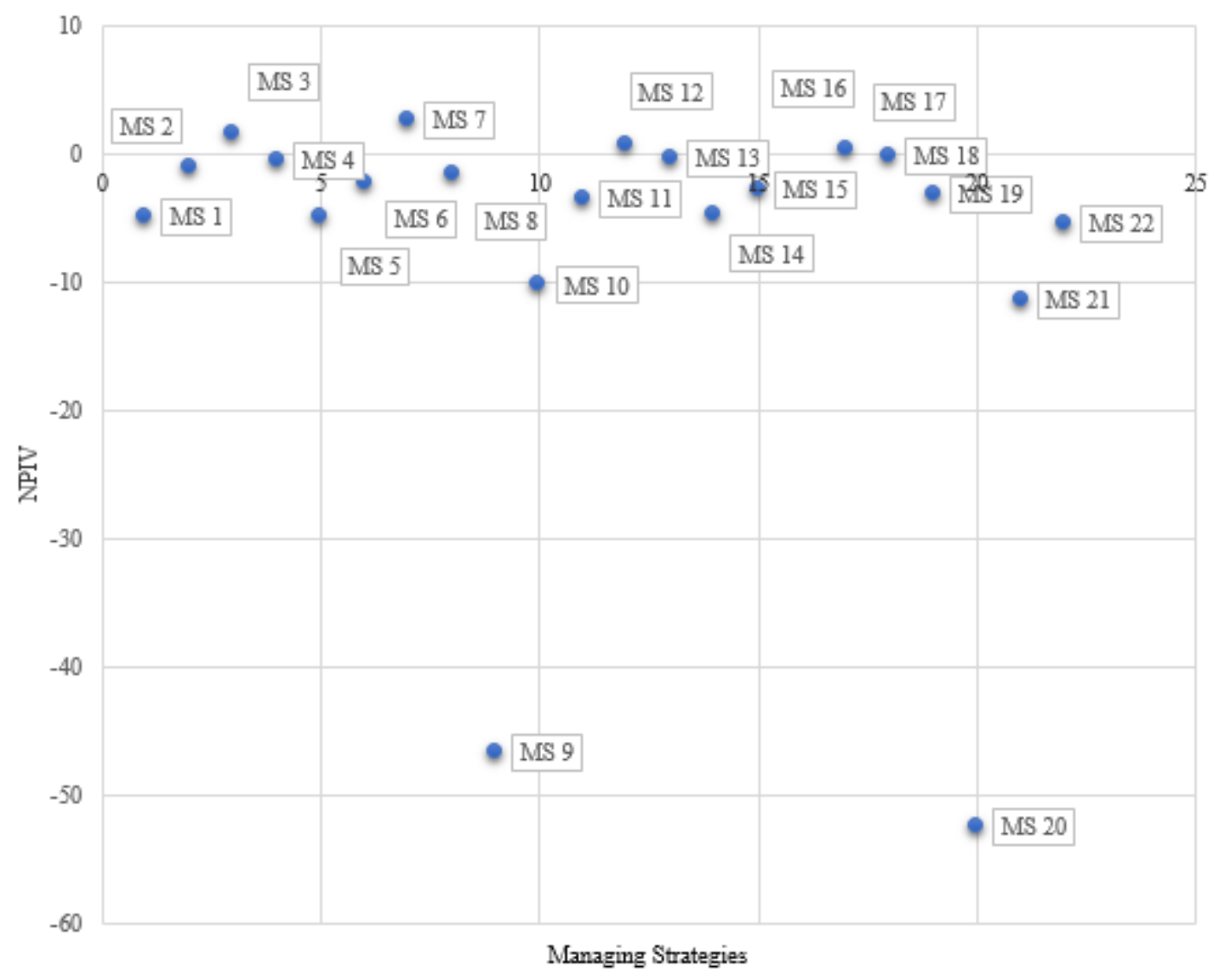

Figure 5. Net positive influence values (NPIV) of the strategies.

\subsection{Significance of Key Findings}

From Figure 5, the strategies with positive NPIV values were selected as the key findings of the paper.

Manufacturing flexibility (MS 7) comes in the first position. Manufacturing flexibility is very important for production sustainability. It plays an important role in high-mix low volume production plants [87]. During this COVID-19 outbreak, manufacturing flexibility can help manufacturing firms minimize their risks by attracting new buyers to increase the products' customization.

Diversify the source of supply and develop backup suppliers (MS 3) ranks second according to NPIV value. It increases the responsiveness of the supply chain [88]. Due to the COVID-19 outbreak, many ports in the world remained shut down, which halted raw material supply from many trusted suppliers for the manufacturing firms. This situation has created an urge to develop a backup supplier 
pool to sustain business. During this outbreak, many big manufacturing firms did not have alternating sourcing channels and suffered a loss of millions of dollars due to incomplete orders.

Train backup operators (MS 12) rank in third place among the other strategies. When a worker is not available, management must immediately struggle to find a substitute. As the COVID-19 outbreak situation is unpredictable, anyone could be affected by COVID-19 at any time. If a company does not have any backup operator, the production may be disrupted once COVID-19 affects any operator. So, backup operators must be trained and made available for every time they are needed. Training employees to perform multiple tasks also alleviates this problem [89].

Supply chain design adjustment (MS 17) comes next and concludes the ranking of the strategy. COVID-19 outbreak has a significant impact on each and every stage of the SC network, i.e., some transportation modes may have been affected, the bottleneck in the production line [90], etc. It is also challenging to do effective forecasting during the pandemic outbreak, which is vital for improvement in supply-chain planning [91]. Every RMG industry should focus on the supply chain network design problems by considering economies of scale and demand fluctuations [92]. So, all SC stages should be redesigned and adjusted from time to time concerning the situation.

\section{Implications of This Study}

In this study, several possible strategies to deal with the impacts of the COVID-19 pandemic in the RMG supply chain have been presented. This section includes some theoretical and practical implications of the study for improving economic and social sustainability across the supply chain.

\subsection{Implications to Theory}

The COVID-19 pandemic affects the global economic system from the supply perspective [22]. The fast spatial spread of the COVID-19 pandemic, with the unforeseeable scaling and ripple consequence, has resulted in one of the most significant economic disruptions in the last several decades [26]. On the other hand, investigating SC strategies has commonly been studied in various conditions for a variety of industries. Therefore, this work contributes to addressing the requirement of finding several possible strategies to deal with the impacts of the COVID-19 pandemic in the supply chain topic.

This research advances theory of mitigating the COVID-19 pandemic risk by proposing a methodological framework based on the grey theory and digraph-matrix methods. The proposed methodology was able to efficiently recognize strategies to manage the COVID-19 pandemic risk in a real-world setting of an emerging economy.

This study presents a comprehensive list of strategies to manage the impacts of the COVID-19 pandemic. Academics can use these strategies to advance research on improving the economic and social sustainability of supply chains in emerging economies.

\subsection{Implications for Practice}

Supply chain disruption is observed around the world as the consequence of this outbreak of COVID-19, and the disruption is expected to continue for several months or years, given the interconnectedness and complexity of global supply chains. Strong supply disruptions will impede development all over the world. Therefore, the supply chain systems need to be integrated, and their competitive capacities need to be enhanced through practicing strategies to alleviate the adverse impacts. Proactively addressing the potential impacts of such disruption is important for any organization's top management to make proper strategies and tactics at the right time. The main objective of this research was to identify the most important possible strategies for managing the impacts of the COVID-19 pandemic in the supply chain and improving economic and social sustainability during this outbreak situation.

The results of the study can be inspected as necessary guidance for various management professionals and policymakers to successfully identify and implement the possible strategies with 
the target of improving economic and social sustainability. This can be observed in practice to ensure better implementation of possible strategies.

The proposed model in this study (a blended grey theory and digraph-matrix) is suggested to test the possible strategies for Bangladesh's readymade garments industry. This model could enable policymakers to take proactive initiatives in the same situation. Each strategic decision can be sorted out based on priority ranking. The following conclusions for the case are mentioned, and it is recommended that managers focus on the most significant and notable strategies that have the utmost importance over the impacts. Impact strategies are structured to minimize, eliminate, or monitor the effect of known or unknown risks. To counter these unforeseen risk factors and their related vulnerabilities, organizations' managers should practice high levels of visibility and collaboration. The top management and policymakers should acknowledge the importance of systemically identifying possible strategies that are crucial and sensitive towards the impacts of such disruption events.

\section{Conclusions, Limitations and Future Research Directions}

This study contributes to ascertain and construct a structured framework to grade or rank possible strategies archetypally seen in RMG supply chains in order to assuage the inevitable yet explicit impacts of the COVID-19 outbreak. In today's markets, while managing the vulnerability of this major outbreak event COVID-19, the RMG industry needs to continue to increase the versatility as well as the flexibility of their respective supply chains in order to improve economic as well as social sustainability. This rapid global change and its associated impacts cannot be resolved without implementing specific possible strategies. Hence, this study integrates the grey theory and digraph-matrix to assess the ranking among strategies so that the top-ranked possible strategies should get more priority to be implemented in the RMG supply chain. It is evident from this research that the strategies and the impacts of the COVID-19 outbreak are interlinked and have significant influences on each other. The RMG supply chain from Bangladesh is purposefully selected in this research to test the model. The key findings reveal that strategies for "manufacturing flexibility", "diversify the source of supply", and "develop backup suppliers" have significant repercussions on the RMG supply chain.

In conclusion, the research's advantages are twofold: first, to recognize and categorize the impacts and possible strategies required to manage the adverse impacts of major supply chain disturbances considering the current COVID-19 outbreak situation, and second, to clearly classify the prominent possible strategies, which managers and practitioners might potentially focus on.

There are some drawbacks to this investigation as well. Firstly, this study is carried out at a macro level. An overview of strategies influencing the micro-level impacts of this disruption risk COVID-19 outbreak may generate more insight into the RMG supply chain. A study of micro-level strategies affecting the impacts of supply chain disruption risk may be seen as a framework for future work. This research contains contributions from supply chain administrators, senior managers, and scholars. There may be chances of bias because the values taken for various factors of pairwise comparison among impacts and possible strategies are based on inputs given by case organization managers. To deliver those ratings, analysts need to have an exhaustive knowledge of the firm, its practices, and the potential risk events associated with their supply chains from past data. A large number of pairwise comparisons amid impacts and possible strategies to manage those impacts had to be performed by professionals for this analysis. Fatigue is definitely a possibility that may cause some issues with reliability. The use of a specified grey-scale meaning for a linguistic variable is an additional constraint. To assess the sensitivity of the solution, assignment and dispersion of the grey scale could be explored.

Analyzing the limitations of the current study, the researchers can verify this paper's result in different industrial sectors, such as education, transport, pharmaceutical, furniture etc. In addition to that, instead of grey theory, a fuzzy grey theory may be introduced. The result can be compared to discovering whether there is a substantial difference in the ranking order. Considering the possible strategies of different impacts in certain supply chains, the findings may be generalized to other supply 
chains. The proposed framework may be further modified in the context of the circular economy's emerging business environment, internet of things (IoT), and Industry 4.0.

Supplementary Materials: The following are available online at http://www.mdpi.com/2071-1050/12/22/9483/s1, Table S1: Initial relation matrix displaying relative importance of Impact (Expert-1). Table S2: Initial relation matrix displaying relative importance of Impact (Expert-2). Table S3: Initial relation matrix displaying relative importance of Impact (Expert-3). Table S4: Initial relation matrix displaying positive influence of strategies over Impact (Expert-1). Table S5: Initial relation matrix displaying negative influence of strategies over Impact (Expert-1). Table S6: Relative importance of Impact using grey scale low value (Expert-1). Table S7: Relative importance of Impact using grey scale low value (Expert-2). Table S8: Relative importance of Impact using grey scale low value (Expert-3). Table S9: Relative importance of Impact using grey scale high value (Expert-1). Table S10: Relative importance of Impact using grey scale high value (Expert-2). Table S11: Relative importance of Impact using grey scale high value (Expert-3). Table S12: Average grey relation matrix displaying relative importance of Impact using grey scale low value. Table S13: Average grey relation matrix displaying relative importance of Impact using grey scale high value.

Author Contributions: Conceptualization, H.M.M.T., H.N.A., S.P., S.M.A., G.K., S.K.P.; methodology, H.M.M.T., H.N.A., S.P., S.M.A., G.K., S.K.P.; software, H.M.M.T., H.N.A., S.P.; validation H.M.M.T., H.N.A., S.P.; formal analysis, H.M.M.T., H.N.A., S.P.; investigation, H.M.M.T., H.N.A., S.P., M.G., S.M.A., G.K., S.K.P.; resources, S.M.A., G.K., S.K.P., S.M.A., G.K., S.K.P.; data curation, H.M.M.T., H.N.A., S.P.; writing-original draft preparation, H.M.M.T., H.N.A., S.P., M.G.; writing-review and editing, M.G., S.M.A., G.K., S.K.P.; visualization, H.M.M.T., H.N.A., S.P., M.G.; supervision, S.M.A., G.K., S.K.P.; project administration, S.M.A., G.K., S.K.P. All authors have read and agreed to the published version of the manuscript. The first three authors contributed equally to this paper and hold the first authorship.

Funding: This research received no external funding.

Acknowledgments: This research was undertaken in Bangladesh University of Engineering and Technology (BUET). The authors acknowledge the supports received from the Department of Industrial and Production Engineering of BUET to conduct this research successfully.

Conflicts of Interest: The authors declare no conflict of interest.

\section{List of Notations Along with Abbreviations}

\begin{tabular}{|c|c|}
\hline SC & Supply Chain \\
\hline GST & Grey System Theory \\
\hline IM1-IM10 & Listed Impact \\
\hline MS1-MS22 & Listed Possible Managing Strategies \\
\hline CFCS & Converting the Fuzzy data into Crisp Scores \\
\hline NPIV & Net Positive Influence Value \\
\hline$i, j, y$ & Impacts \\
\hline$x$ & Strategies \\
\hline$L$ & Each respondent \\
\hline K & Total number of respondents \\
\hline$m$ & Total number of impacts \\
\hline$n$ & Total number of strategies \\
\hline [] & Matrix \\
\hline$\otimes \mathrm{P}_{\mathrm{ij}}^{\mathrm{L}}, \otimes \mathrm{Q}_{\mathrm{xy}}^{\mathrm{L}}, \otimes \mathrm{R}_{\mathrm{xy}}^{\mathrm{L}}$ & Grey Numbers for a respondent L \\
\hline$\otimes \mathrm{P}_{\mathrm{ij}}^{\mathrm{L}}, \underline{\otimes} \mathrm{Q}_{x y}^{\mathrm{L}}, \underline{\otimes} \mathrm{R}_{x y}^{\mathrm{L}}$ & Lower values of grey numbers for a respondent $L$ \\
\hline $\bar{\otimes} \mathrm{P}_{\mathrm{ij}}^{\mathrm{L}}, \overline{\bar{\otimes}} \mathrm{Q}_{\mathrm{xy}}^{\mathrm{L}}, \overline{\bar{\otimes}} \mathrm{R}_{\mathrm{xy}}^{\mathrm{L}}$ & Upper values of grey numbers for a respondent $L$ \\
\hline$\left[\otimes \widetilde{P}_{\mathrm{ij}}\right],\left[\otimes \widetilde{Q}_{\mathrm{xy}}\right],\left[\otimes \widetilde{R}_{\mathrm{xy}}\right]$ & Average grey relation matrices \\
\hline$\underline{\otimes P} \dot{\mathrm{ij}}^{\prime} \otimes \mathrm{Q}_{\mathrm{xy}}, \underline{\otimes \mathrm{R}_{\mathrm{xy}}}$ & Normalized lower limit value \\
\hline $\bar{\otimes} P_{i j}, \bar{\otimes} Q_{x y}, \bar{\otimes} R_{x y}$ & Normalized upper limit value \\
\hline$a_{i j}, b_{x y}, c_{x y}$ & Normalized crisp value \\
\hline$u_{i j}, v_{x y}, w_{x y}$ & Final crisp value \\
\hline$\Delta_{\min }^{\max }, \alpha_{\min }^{\max }, \beta_{\min }^{\max }$ & $\begin{array}{l}\text { Difference between maximum normalized upper grey values and minimum } \\
\text { normalized lower grey values }\end{array}$ \\
\hline $\mathrm{U}^{*}, \mathrm{~V}^{*}, \mathrm{~W}^{*}$ & Crisp relation matrices \\
\hline $\mathrm{D}$ & Strategy selection matrix for the positive influence of strategies over impacts \\
\hline E & Strategy selection matrix for the negative influence of strategies over impacts \\
\hline I & Permanent function matrix \\
\hline
\end{tabular}




\section{Appendix A}

Table A1. Experts and their designation.

\begin{tabular}{ccc}
\hline Expert Name & Designation & Experience (Years) \\
\hline Expert 1 & General Manager, Human Resource, Hameem Group & 25 \\
\hline Expert 2 & Manager, SC Department, Beximco Textile Mills Ltd. & 22 \\
\hline Expert 3 & Managing Director, Dulal Brothers Limited & 30 \\
\hline Expert 4 & Senior Manager, SC Department, Epyllion Group & 24 \\
\hline Expert 5 & Deputy general manager, Ananta Group & 35 \\
\hline
\end{tabular}

\section{References}

1. Ivanov, D.; Dolgui, A. A Digital Supply Chain Twin for Managing the Disruption Risks and Resilience in the Era of Industry 4.0. Prod. Plan. Control 2020, 1-14. [CrossRef]

2. Wang, P.; Zheng, X.; Li, J.; Zhu, B. Prediction of Epidemic Trends in COVID-19 with Logistic Model and Machine Learning Technics. Chaos Solitons Fractals 2020, 139, 110058. [CrossRef]

3. WHO. WHO Coronavirus Disease (COVID-19) Dashboard | WHO Coronavirus Disease (COVID-19) Dashboard. Available online: https:/covid19.who.int/?gclid=Cj0KCQjwtsv7BRCmARIsANuCQflCfofaf9y8JIGS31c5vZCgBtKRNCJswQWiVPYypnbio5h8dvEWI4aAr5IEALw_wcB (accessed on 29 September 2020).

4. Iyengar, K.; Mabrouk, A.; Jain, V.K.; Venkatesan, A.; Vaishya, R. Learning Opportunities from COVID-19 and Future Effects on Health Care System. Diabetes Metab. Syndr. Clin. Res. Rev. 2020, 14, 943-946. [CrossRef]

5. Rothan, H.A.; Byrareddy, S.N. The Epidemiology and Pathogenesis of Coronavirus Disease (COVID-19) Outbreak. J. Autoimmun. 2020, 109, 102433. [CrossRef]

6. Amankwah-Amoah, J.; Khan, Z.; Wood, G. COVID-19 and Business Failures: The Paradoxes of Experience, Scale, and Scope for Theory and Practice. Eur. Manag. J. 2020. [CrossRef]

7. Fortune. Coronavirus Impact: $94 \%$ of the Fortune 1000 Are Seeing Supply Chain Disruptions. Fortune. Available online: https:/fortune.com/2020/02/21/fortune-1000-coronavirus-china-supply-chain-impact/ (accessed on 22 August 2020).

8. Ivanov, D. Predicting the Impacts of Epidemic Outbreaks on Global Supply Chains: A Simulation-Based Analysis on the Coronavirus Outbreak (COVID-19/SARS-CoV-2) Case. Transp. Res. Part E Logist. Transp. Rev. 2020, 136, 101922. [CrossRef]

9. Li, W.-Y.; Chow, P.-S.; Choi, T.-M.; Chan, H.-L. Supplier Integration, Green Sustainability Programs, and Financial Performance of Fashion Enterprises under Global Financial Crisis. J. Clean. Prod. 2016, 135, 57-70. [CrossRef]

10. Mustafid, N.; Karimariza, S.A.; Jie, F. Supply Chain Agility Information Systems with Key Factors for Fashion Industry Competitiveness. Int. J. Agil. Syst. Manag. 2018, 11, 1-22. [CrossRef]

11. da Silva, P.C.; de Oliveira Neto, G.C.; Correia, J.M.F.; Tucci, H.N.P. Evaluation of Economic, Environmental and Operational Performance of the Adoption of Cleaner Production: Survey in Large Textile Industries. J. Clean. Prod. 2021, 278, 123855. [CrossRef]

12. Patel, R.; Babady, E.; Theel, E.S.; Storch, G.A.; Pinsky, B.A.; George, K.S.; Smith, T.C.; Bertuzzi, S. Report from the American Society for Microbiology Covid-19 International Summit, 23 March 2020: Value of Diagnostic Testing for Sars-Cov-2/Covid-19. mBio. 2020, 11. [CrossRef] [PubMed]

13. Donthu, N.; Gustafsson, A. Effects of COVID-19 on Business and Research. J. Bus. Res. 2020, 117, $284-289$. [CrossRef] [PubMed]

14. Majumdar, A.; Shaw, M.; Sinha, S.K. COVID-19 Debunks the Myth of Socially Sustainable Supply Chain: A Case of the Clothing Industry in South Asian Countries. Sustain. Prod. Consum. 2020, 24, 150-155. [CrossRef]

15. Paul, S.; Venkateswaran, J. Impact of Drug Supply Chain on the Dynamics of Infectious Diseases. Syst. Dyn. Rev. 2017, 33, 280-310. [CrossRef]

16. Rizou, M.; Galanakis, I.M.; Aldawoud, T.M.S.; Galanakis, C.M. Safety of Foods, Food Supply Chain and Environment within the COVID-19 Pandemic. Trends Food Sci. Technol. 2020, 102, 293-299. [CrossRef] 
17. Fan, V.Y.; Jamison, D.T.; Summers, L.H. Pandemic Risk: How Large Are the Expected Losses? Bull. World Health Organ. 2018, 96, 129-134. [CrossRef]

18. Barua, S. Understanding Coronanomics: The Economic Implications of the Coronavirus (COVID-19) Pandemic. SSRN Electron. J. 2020. [CrossRef]

19. Hobbs, J.E. Food Supply Chains during the COVID-19 Pandemic. Can. J. Agric. Econ. Can. D'agroeconomie 2020, 68, 171-176. [CrossRef]

20. Joshi, P.; Kulkarni, U.; Munje, S.; Kulkarni, S. Impact of Covid-19 Pandemic on Indian Fruits and Vegetables Export, Postharvest Management Supply Chain and Future Strategies. AgricINTERNATIONAL 2019, 6, 4. [CrossRef]

21. He, P.; Niu, H.; Sun, Z.; Li, T. Accounting Index of COVID-19 Impact on Chinese Industries: A Case Study Using Big Data Portrait Analysis. Emerg. Mark. Financ. Trade 2020, 56, 2332-2349. [CrossRef]

22. Guan, D.; Wang, D.; Hallegatte, S.; Davis, S.J.; Huo, J.; Li, S.; Bai, Y.; Lei, T.; Xue, Q.; Coffman, D.M.; et al. Global Supply-Chain Effects of COVID-19 Control Measures. Nat. Hum. Behav. 2020, 4, 577-587. [CrossRef]

23. Nicola, M.; Alsafi, Z.; Sohrabi, C.; Kerwan, A.; Al-Jabir, A.; Iosifidis, C.; Agha, M.; Agha, R. The Socio-Economic Implications of the Coronavirus Pandemic (COVID-19): A Review. Int. J. Surg. 2020, 78, 185-193. [CrossRef] [PubMed]

24. Elleby, C.; Domínguez, I.P.; Adenauer, M.; Genovese, G. Impacts of the COVID-19 Pandemic on the Global Agricultural Markets. Environ. Resour. Econ. 2020, 76, 1067-1079. [CrossRef] [PubMed]

25. Benítez, C.Y.; Güemes, A.; Aranda, J.; Ribeiro, M.; Ottolino, P.; Di Saverio, S.; Alexandrino, H.; Ponchietti, L.; Blas, J.L.; Ramos, J.P.; et al. Impact of Personal Protective Equipment on Surgical Performance during the COVID-19 Pandemic. World J. Surg. 2020, 44, 2842-2847. [CrossRef]

26. Yu, K.D.S.; Aviso, K.B. Modelling the Economic Impact and Ripple Effects of Disease Outbreaks. Process Integr. Optim. Sustain. 2020, 4, 183-186. [CrossRef]

27. Baldwin, R.; di Mauro, B.W. Economics in the Time of COVID-19; Centre for Economic Policy Research: London, UK, 2020; Volume 26, A VoxEU. org Book.

28. Marsh, K. TACCP and VACCP Demystified! International Food Safety \& Quality Network: Lancashire, UK, 2015.

29. Jawed, I.; Tareen, F.R.; Cauhan, K.; Nayeem, M. Food Safety and COVID-19: Limitations of HACCP and the Way Forward. Pharma Innov. 2020, 9, 1-4. [CrossRef]

30. Iivari, N.; Sharma, S.; Ventä-Olkkonen, L. Digital Transformation of Everyday Life-How COVID-19 Pandemic Transformed the Basic Education of the Young Generation and Why Information Management Research Should Care? Int. J. Inf. Manag. 2020, 55, 102183. [CrossRef]

31. Ivanov, D.; Dolgui, A. Low-Certainty-Need (LCN) Supply Chains: A New Perspective in Managing Disruption Risks and Resilience. Int. J. Prod. Res. 2019, 57, 5119-5136. [CrossRef]

32. Son, J.; Kang, J.H.; Jang, S. The Effects of Out-of-Stock, Return, and Cancellation Amounts on the Order Amounts of an Online Retailer. J. Retail. Consum. Serv. 2019, 51, 421-427. [CrossRef]

33. Zhang, Y.; Diao, X.; Chen, K.Z.; Robinson, S.; Fan, S. Impact of COVID-19 on China's Macroeconomy and Agri-Food System-An Economy-Wide Multiplier Model Analysis. China Agric. Econ. Rev. 2020, 12, 387-407. [CrossRef]

34. Sánchez-Ramírez, C.; Ramos-Hernández, R.; Fong, J.R.M.; Alor-Hernández, G.; García-Alcaraz, J.L. A System Dynamics Model to Evaluate the Impact of Production Process Disruption on Order Shipping. Appl. Sci. 2019, 10, 208. [CrossRef]

35. Altig, D.; Baker, S.; Barrero, J.M.; Bloom, N.; Bunn, P.; Chen, S.; Davis, S.J.; Leather, J.; Meyer, B.; Mihaylov, E.; et al. Economic Uncertainty before and during the COVID-19 Pandemic. J. Public Econ. 2020, 191, 104274. [CrossRef]

36. Gereffi, G. What Does the COVID-19 Pandemic Teach Us about Global Value Chains? The Case of Medical Supplies. J. Int. Bus. Policy 2020, 3, 287-301. [CrossRef]

37. Pradhan, S.; Ghose, D. Present and Future Impact of COVID-19 in the Renewable Energy Sector: A Case Study on India. Energy Sources Part A Recover. Util. Environ. Eff. 2020, 1-11. [CrossRef]

38. Publicis Sapient. COVID-19: Preparing Your Supply Chain in Times of Crisis | Publicis Sapient. Available online: https://www.publicissapient.com/insights/coronavirus_and_managing_the_supply_chain_ amid_a_crisis (accessed on 19 July 2020).

39. Tang, C.S.; Zimmerman, J. Information and Communication Technology for Managing Supply Chain Risks. Commun. ACM 2013, 56, 27-29. [CrossRef] 
40. Vidya, C.T.; Prabheesh, K.P. Implications of COVID-19 Pandemic on the Global Trade Networks. Emerg. Mark. Financ. Trade 2020, 56, 2408-2421. [CrossRef]

41. Ansari, Z.N.; Kant, R.; Shankar, R. Evaluation and Ranking of Solutions to Mitigate Sustainable Remanufacturing Supply Chain Risks: A Hybrid Fuzzy SWARA-Fuzzy COPRAS Framework Approach. Int. J. Sustain. Eng. 2020, 1-22. [CrossRef]

42. Khan, S.; Haleem, A.; Khan, M.I. Assessment of Risk in the Management of Halal Supply Chain Using Fuzzy BWM Method. Supply Chain Forum Int. J. 2020, 1-17. [CrossRef]

43. Ali, S.M.; Moktadir, M.A.; Kabir, G.; Chakma, J.; Rumi, M.J.U.; Islam, M.T. Framework for Evaluating Risks in Food Supply Chain: Implications in Food Wastage Reduction. J. Clean. Prod. 2019, 228, 786-800. [CrossRef]

44. Surya, P.; Gunjan, S.; Singh, R.A.P.; Shubhender, S. Risk Analysis and Mitigation for Perishable Food Supply Chain: A Case of Dairy Industry. Benchmarking Int. J. 2017, 24, 2-23. [CrossRef]

45. Shahbaz, K.; Imran, K.M.; Abid, H.; Rahman, J.A. Prioritising the Risks in Halal Food Supply Chain: An MCDM Approach. J. Islamic Mark. 2019. [CrossRef]

46. Mzougui, I.; Carpitella, S.; Certa, A.; El Felsoufi, Z.; Izquierdo, J. Assessing Supply Chain Risks in the Automotive Industry through a Modified MCDM-Based FMECA. Processes 2020, 8, 579. [CrossRef]

47. Pourjavad, E.; Shahin, A. A Hybrid Model for Analyzing the Risks of Green Supply Chain in a Fuzzy Environment. J. Ind. Prod. Eng. 2020, 37, 422-433. [CrossRef]

48. Moktadir, M.A.; Dwivedi, A.; Khan, N.S.; Paul, S.K.; Khan, S.A.; Ahmed, S.; Sultana, R. Analysis of Risk Factors in Sustainable Supply Chain Management in an Emerging Economy of Leather Industry. J. Clean. Prod. 2020, 124641. [CrossRef]

49. Mahesh, C.; Tilak, R.; Ravi, S.; Aashish, A. Select the Best Supply Chain by Risk Analysis for Indian Industries Environment Using MCDM Approaches. Benchmarking Int. J. 2017, 24, 1400-1413. [CrossRef]

50. Golinska, P.; Kosacka, M.; Mierzwiak, R.; Werner-Lewandowska, K. Grey Decision Making as a Tool for the Classification of the Sustainability Level of Remanufacturing Companies. J. Clean. Prod. 2015, 105, $28-40$. [CrossRef]

51. Rajesh, R.; Ravi, V. Supplier Selection in Resilient Supply Chains: A Grey Relational Analysis Approach. J. Clean. Prod. 2015, 86, 343-359. [CrossRef]

52. Chen, L.; Zhou, Y.; Zhou, D.; Xue, L. Clustering Enterprises into Eco-Industrial Parks: Can Interfirm Alliances Help Small and Medium-Sized Enterprises? J. Clean. Prod. 2017, 168, 1070-1079. [CrossRef]

53. Mathivathanan, D.; Govindan, K.; Haq, A.N. Exploring the Impact of Dynamic Capabilities on Sustainable Supply Chain Firm's Performance Using Grey-Analytical Hierarchy Process. J. Clean. Prod. 2017, 147, 637-653. [CrossRef]

54. Xue, J.; Van Gelder, P.H.A.J.M.; Reniers, G.; Papadimitriou, E.; Wu, C. Multi-Attribute Decision-Making Method for Prioritizing Maritime Traffic Safety Influencing Factors of Autonomous Ships' Maneuvering Decisions Using Grey and Fuzzy Theories. Saf. Sci. 2019, 120, 323-340. [CrossRef]

55. Wang, H.; Zhang, Y.-M.; Yang, Z. A Risk Evaluation Method to Prioritize Failure Modes Based on Failure Data and a Combination of Fuzzy Sets Theory and Grey Theory. Eng. Appl. Artif. Intell. 2019, 82, 216-225. [CrossRef]

56. Liu, H.-C.; Chen, Y.-Z.; You, J.-X.; Li, H. Risk Evaluation in Failure Mode and Effects Analysis Using Fuzzy Digraph and Matrix Approach. J. Intell. Manuf. 2016, 27, 805-816. [CrossRef]

57. Geetha, N.K.; Sekar, P. Graph Theory Matrix Approach-A Qualitative Decision Making Tool. Mater. Today Proc. 2017, 4, 7741-7749. [CrossRef]

58. Rajesh, R.; Ravi, V.; Rao, R.V. Selection of Risk Mitigation Strategy in Electronic Supply Chains Using Grey Theory and Digraph-Matrix Approaches. Int. J. Prod. Res. 2014, 53, 238-257. [CrossRef]

59. Yue, X.; Xu, W.; Zhang, Y.; Du, L. Analysis of Global Properties for Dynamical Systems by a Modified Digraph Cell Mapping Method. Chaos Solitons Fractals 2018, 111, 206-212. [CrossRef]

60. Srivastava, P.; Khanduja, D.; Ganesan, S.; Agarwal, M.; Tulsiyan, M.; Tandon, M.; Gupta, S. Risk Analysis of CNG Dispensing Unit by Fuzzy Digraph Matrix and Dempster-Shafer Approach. Int. J. Product. Qual. Manag. 2019, 28, 227-255. [CrossRef]

61. Dias, G.C.; Hernandez, C.T.; de Oliveira, U.R. Supply Chain Risk Management and Risk Ranking in the Automotive Industry. Gest. Prod. 2020, 27, 2020. [CrossRef]

62. Rajesh, R.; Ravi, V. Modeling Enablers of Supply Chain Risk Mitigation in Electronic Supply Chains: A Grey-DEMATEL Approach. Comput. Ind. Eng. 2015, 87, 126-139. [CrossRef] 
63. Chowdhury, M.T.; Sarkar, A.; Paul, S.K.; Moktadir, A. A Case Study on Strategies to Deal with the Impacts of COVID-19 Pandemic in the Food and Beverage Industry. Oper. Manag. Res. 2020,1-13. [CrossRef]

64. Paul, S.K.; Chowdhury, P. Strategies for Managing the Impacts of Disruptions During COVID-19: An Example of Toilet Paper. Glob. J. Flex. Syst. Manag. 2020, 21, 283-293. [CrossRef]

65. Rajesh, R. A Grey-Layered ANP Based Decision Support Model for Analyzing Strategies of Resilience in Electronic Supply Chains. Eng. Appl. Artif. Intell. 2020, 87, 103338. [CrossRef]

66. Brown, E.E.; Kumar, S.; Rajji, T.K.; Pollock, B.G.; Mulsant, B.H. Anticipating and Mitigating the Impact of the COVID-19 Pandemic on Alzheimer's Disease and Related Dementias. Am. J. Geriatr. Psychiatry 2020, 28, 712-721. [CrossRef]

67. de Bruin, Y.B.; Lequarre, A.-S.; McCourt, J.; Clevestig, P.; Pigazzani, F.; Jeddi, M.Z.; Colosio, C.; Goulart, M. Initial Impacts of Global Risk Mitigation Measures Taken during the Combatting of the COVID-19 Pandemic. Saf. Sci. 2020, 128, 104773. [CrossRef]

68. Ma, J.; Hou, S.; Bao, B. Short-Term and Long-Term Impacts of a Quick Response Strategy on a Dual Channel Apparel Supply Chain. Int. J. Bifurc. Chaos 2019, 29, 1950190. [CrossRef]

69. Bain, M. (2020). Coronavirus threatens the livelihoods of garment workers around the world. Qz.Com. Available online: https:/qz.com/1821511/coronavirus-threatens-jobs-of-garmentworkers-in-southeast-asia/ (accessed on 19 July 2020).

70. Ju-Long, D. Control Problems of Grey Systems. Syst. Control Lett. 1982, 1, 288-294. [CrossRef]

71. Kabir, G.; Sumi, R.S. Integrating fuzzy Delphi with graph theory and matrix methods for evaluation of hazardous industrial waste transportation firm. Int. J. Logist. Econ. Glob. 2012, 4, 221-237. [CrossRef]

72. Singh, R.K.; Kumar, P. Measuring the Flexibility Index for a Supply Chain Using Graph Theory Matrix Approach. J. Glob. Oper. Strateg. Sourc. 2019, 13, 56-69. [CrossRef]

73. Opricovic, S.; Tzeng, G.H. Defuzzification within a Multicriteria Decision Model. Int. J. Uncertain. Fuzziness Knowl. Based Syst. 2003, 11, 635-652. [CrossRef]

74. Fu, X.; Zhu, Q.; Sarkis, J. Evaluating Green Supplier Development Programs at a Telecommunications Systems Provider. Int. J. Prod. Econ. 2012, 140, 357-367. [CrossRef]

75. Rajesh, R.; Ravi, V. Analyzing Drivers of Risks in Electronic Supply Chains: A Grey-DEMATEL Approach. Int. J. Adv. Manuf. Technol. 2017, 92, 1127-1145. [CrossRef]

76. Wang, Y.; Yu, Y. Flexible Strategies under Supply Disruption: The Interplay between Contingent Sourcing and Responsive Pricing. Int. J. Prod. Res. 2020, 58, 1-22. [CrossRef]

77. Hou, J.; Sun, L. Backup Sourcing Decisions for Coping with Supply Disruptions under Long-Term Horizons. Discret. Dyn. Nat. Soc. 2016, 2016, 6716058. [CrossRef]

78. Sharif, S. Impact of COVID-19 Pandemic: Government Relief Package and the Likely Mis-Allocation of Loans in Pakistan. SSRN Electron. J. 2020. [CrossRef]

79. Kumar, P.S.; Priyabrata, C. A Production Recovery Plan in Manufacturing Supply Chains for a High-Demand Item during COVID-19. Int. J. Phys. Distrib. Logist. Manag. 2020. [CrossRef]

80. Sen, S.; Antara, N.; Sen, S.; Chowdhury, S. The Unprecedented Pandemic "COVID-19" Effect on the Bangladesh Apparel Workers by Shivering the Apparel Supply Chain. SSRN Electron. J. 2020. [CrossRef]

81. WHO. Q\&A: Tips for Health and Safety at the Workplace in the Context of COVID-19. Available online: https:/www.who.int/news-room/q-a-detail/q-a-tips-for-health-and-safety-at-the-workplacein-the-context-of-covid-19?gclid=Cj0KCQjw3s_4BRDPARIsAJsyoLMiMKfepPADnBPUjAnCBnzDaIIZbdoV4VXwnTeLfdzOl8p39gMFHEaAjkxEALw_wcB (accessed on 20 July 2020).

82. Kramer, A.; Kramer, K.Z. The Potential Impact of the Covid-19 Pandemic on Occupational Status, Work from Home, and Occupational Mobility. J. Vocat. Behav. 2020, 119, 103442. [CrossRef]

83. Novak, J.I.; Loy, J. A Critical Review of Initial 3D Printed Products Responding to COVID-19 Health and Supply Chain Challenges. Emerald Open Res. 2020, 2, 24. [CrossRef]

84. Parast, M.M. The Impact of R\&D Investment on Mitigating Supply Chain Disruptions: Empirical Evidence from U.S. Firms. Int. J. Prod. Econ. 2020, 227, 107671. [CrossRef]

85. Huo, B.; Haq, M.Z.U.; Gu, M. The Impact of Information Sharing on Supply Chain Learning and Flexibility Performance. Int. J. Prod. Res. 2020, 1-24. [CrossRef]

86. Govindan, K.; Roohollah, K.; Amin, V. A Grey DEMATEL Approach to Develop Third-Party Logistics Provider Selection Criteria. Ind. Manag. Data Syst. 2018, 116, 690-722. [CrossRef] 
87. Mishra, R. Empirical Analysis of Enablers and Performance Outcome of Manufacturing Flexibility in an Emerging Economy. J. Manuf. Technol. Manag. 2020. [CrossRef]

88. Golmohammadi, A.; Hassini, E. Review of Supplier Diversification and Pricing Strategies under Random Supply and Demand. Int. J. Prod. Res. 2020, 58, 3455-3487. [CrossRef]

89. Inman, R.R.; Jordan, W.C.; Blumenfeld, D.E. Chained Cross-Training of Assembly Line Workers. Int. J. Prod. Res. 2004, 42, 1899-1910. [CrossRef]

90. Park, C.-Y.; Kim, K.; Roth, S.; Beck, S.; Kang, J.W.; Tayag, M.C.; Griffin, M. Global Shortage of Personal Protective Equipment amid COVID-19: Supply Chains, Bottlenecks, and Policy Implications. ADB Briefs 2019, 108, 1-8. [CrossRef]

91. Fildes, R.; Goodwin, P.; Lawrence, M.; Nikolopoulos, K. Effective Forecasting and Judgmental Adjustments: An Empirical Evaluation and Strategies for Improvement in Supply-Chain Planning. Int. J. Forecast. 2009, 25, 3-23. [CrossRef]

92. Hsu, C.-I.; Li, H.-C. Reliability Evaluation and Adjustment of Supply Chain Network Design with Demand Fluctuations. Int. J. Prod. Econ. 2011, 132, 131-145. [CrossRef]

Publisher's Note: MDPI stays neutral with regard to jurisdictional claims in published maps and institutional affiliations.

(C) 2020 by the authors. Licensee MDPI, Basel, Switzerland. This article is an open access article distributed under the terms and conditions of the Creative Commons Attribution (CC BY) license (http://creativecommons.org/licenses/by/4.0/). 